\title{
Generation and Use of Cultured Human Primary Myotubes
}

\author{
Lauren Cornall, Deanne Hryciw, \\ Michael Mathai and Andrew McAinch \\ Victoria University \\ Australia
}

\section{Introduction}

Cell culture is a widely used technique in biomedical research. It permits the analysis of cell specific functions which can relate to changes in certain disease states at the single cell level. A number of cell culture models have been established. These include immortalised cell lines which replicate indefinitely in culture and retain the ability to differentiate and primary cell lines which can be isolated directly from the host tissue and grown in culture. However, primary cell lines have limited replicative potential and become senescent in culture. In the case of muscle cells, cell lines can provide a valuable means of investigating physiology in the absence of confounding factors (such as circulating hormones, adipokines and other bioactive molecules) which arise when dealing with the body as a whole.

Human primary cell lines provide additional benefits in research, when compared to immortalised cell lines, as primary cultures have been shown to retain the metabolic characteristics of the tissue donor and thus reflect alterations in metabolism as seen in specific disease states such as obesity and type 2 diabetes mellitus (Gaster et al., 2004; Steinberg et al., 2006). Of particular interest to the treatment of myopathies is the use of human primary myotube cultures which can be isolated from muscle extracts in normal and diseased states. We (Chen et al., 2005; McAinch et al., 2006b; McAinch et al., 2007; Steinberg et al., 2006) and others (Bell et al., 2010; Mott et al., 2000; Thompson et al., 1996) have shown that the resultant myotube cultures retain phenotypic traits of the donor related to defects in fatty acid oxidation, impairment of insulin stimulated glucose uptake, leptin and/or adiponectin resistance. Thus, there is increased clinical relevance associated with the use of primary cell cultures in researching disease pathogenesis, making human primary cell cultures an invaluable tool in assessing aberrant cellular metabolism and how this may be targeted experimentally to alleviate metabolic dysregulation.

In this chapter we aim to provide the reader with a detailed explanation of the methodological considerations in isolating and culturing of human primary myotubes and their subsequent experimental uses. 


\section{Current applications of human primary myotubes}

\subsection{Skeletal muscle cell culture}

The skeletal muscle is a highly metabolically active tissue and has a profound influence over systemic metabolic function through the regulation of carbohydrate and fatty acid metabolism (Baron et al., 1988; Zurlo et al., 1990). Historically, the study of cellular mechanisms regulating skeletal muscle physiology was limited by difficulties in maintaining metabolically viable isolated muscle extracts and the ability to manipulate specific variables in vivo. The development of cell culture models has provided an invaluable tool by which cellular physiology can be studied. Over the last several decades cell culture techniques have evolved and the resultant studies have contributed greatly to the current understanding of cellular metabolism. A vast number of cell types are cultured to investigate pertinent research questions. Typically the cells used in these models will either be an immortalised cell line or a primary cell line, each of which has distinct advantages. Herein, we provide a brief discussion of the development of both immortalised and primary skeletal muscle cell culture models.

\subsubsection{Immortalised cell lines}

Undifferentiated immortalised skeletal muscle cell lines have an indefinite myogenic potential, with cells continuing to undergo mitotic divisions when maintained in the appropriate culture conditions. Accordingly, these cell lines expand rapidly in culture to provide a readily repeatable experimental model and can provide an alternative to isolating primary cell lines. A key consideration with the use of immortalised cell lines is the retention of physiological functions similar to that of the tissue source (Obinata, 2001). Therefore it is important that immortalised cell lines are adequately characterised to demonstrate that differentiated cell lines recapitulate the physiology of the original tissue.

Clonal cell lines were initially derived from transgenic animal models, tumour cells, treatment of cells with carcinogens or arose through mutations of specific cells within primary cultures (Efrat et al., 1988; Obinata, 2001; Richler \& Yaffe, 1970; Todaro \& Green, 1963; Todaro et al., 1963). These cells do not readily respond to the normal apopotic signals and continue to replicate and divide beyond the life span of un-mutated cells. Isolation and cloning of these myogenic cells enables clonal cell lines to be formed. Despite their benefits in experimental molecular and cellular biology, the relative lack of clonal cell lines and the difficulty in generating new cell lines has inhibited research capacity. More recent techniques utilised to produce immortalised cell lines involve cellular transfection with immortalising genes or oncogenes (Condon et al., 2002; Douillard-Guilloux et al., 2009; Jat et al., 1991). Such methods utilise transfection of genes including telomerase, SV40 Large Tantigen, cyclin-dependent kinase 4 and $\mathrm{Bmi}$ to induce immortalisation of a number of cell types (Condon et al., 2002; Di Donna et al., 2003; Douillard-Guilloux et al., 2009). These methods are limited initially by the number of cells stably expressing the transfected DNA needed to generate a viable population of the immortalised cell line. Additionally, cellular incorporation of the immortalising gene can occur at different sites in theoretically identical cells which can lead to variable gene expression and cellular behaviours. The use of clonal cell lines is further confounded by the potential for the introduced DNA to alter the cellular 
phenotype and therefore cellular physiology (Ridley et al., 1988). This issue may also be apparent in certain cell lines derived from transgenic animal models and tumour cells which reflect the host's expression of certain genes and proteins (Efrat et al., 1988). This may be partially overcome by the generation of conditionally immortalised cell lines in which the effect of the immortalising agent is abrogated under certain culture conditions, such as changes in serum concentrations or temperature (Macpherson et al., 2004; Obinata, 2001).

Immortalised cell lines that are commonly used for investigating skeletal muscle physiology are L6 and $\mathrm{C}_{2} \mathrm{C}_{12}$ skeletal muscle myotubes which are derived from rat and mouse origin, respectively (Blau et al., 1985; Yaffe, 1968; Yaffe \& Saxel, 1977). These cell lines can be terminally differentiated into skeletal muscle myotubes by altering the culture environment to low serum conditions and thus provide a relevant method of investigating muscle physiology.

The L6 cell line was initially described by Yaffe (1968). This cell line was established from newborn rat thigh muscle treated with the carcinogen 20(3) methylcholanthrene in the growth medium during the first two growth passages (Yaffe, 1968). In initial experiments, the L6 cell line was maintained in vitro for more than 18 months without losing the ability to fuse to form differentiated myotubes (Yaffe, 1968). In subsequent studies, Richler \& Yaffe (1970) observed the L6 cell line to develop into multinucleate, cross-striated myotubes which retain contractile properties. The clonal mouse $\mathrm{C}_{2} \mathrm{C}_{12}$ cell line is a diploid sub-clone generated by Blau et al., (1985) as a derivative of the cell line described by Yaffe \& Saxel (1977). This cell line was developed by Yaffe \& Saxel (1977) from thigh muscle of $\mathrm{CH} 3$ mice and was shown to retain the capacity to proliferate and differentiate in culture. The $\mathrm{C}_{2} \mathrm{C}_{12}$ cell line has subsequently been used in muscle physiology studies due to its rapid proliferation and ability to differentiate to form contractile myotubes which express myogenic proteins (Blau et al., 1985; Yaffe \& Saxel, 1977). The initial characterisation of both the L6 and $\mathrm{C}_{2} \mathrm{C}_{12}$ cell lines indicating pronounced differentiation and retention of contractile properties suggest that these cell lines are appropriate models for studying muscle physiology.

\subsubsection{Primary cell lines}

Adult myotubes are not capable of mitotic divisions and therefore primary skeletal muscle culture systems rely on the ability to induce activation and subsequent myogenic differentiation of quiescent satellite cells from within the muscle fibre (Berggren et al., 2007; Blau \& Webster, 1981). Unlike immortalised cell lines, once isolated, primary skeletal muscle cultures are fated for senescence and cease to proliferate after a relatively short period in culture. Consistent with this Machida et al., (2004) showed that with passaging the myogenic potential (as measured by myogenic markers, proliferation and differentiation potential) of rat primary cells to decrease. However primary cells do retain phenotypic traits of the donor cells, and are able to be cultured from small muscle samples of approximately $50 \mathrm{mg}$ to counter this limitation (Berggren et al., 2007; McAinch et al., 2007). For example, studies investigating the phenotype of human primary skeletal muscle myotubes have shown the retention of aberrant glucose metabolism in primary myotubes cultured from insulin resistant Pima Indians (Thompson et al., 1996). Further studies have demonstrated that phenotypic traits of impaired insulin signalling (Bell et al., 2010), fatty acid uptake and oxidation (Bell et al., 2010; Mott et al., 2000), action of the anti -obesogenic and -diabetic adipokines, adiponectin and leptin and aberrant expression of genes which regulate 
substrate metabolism within skeletal muscle (McAinch \& Cameron-Smith, 2009; McAinch et al., 2006b; McAinch et al., 2007) are also retained. Thus, cultured primary myotubes enable the study of muscle cell structure and function in any number of physiological and pathophysiological states. Moreover, cultured myotubes enable the investigation of many metabolic abnormalities that exist in vivo, while eliminating confounding environmental influences on the muscle (such as circulating hormones, adipokines and other bioactive factors). Myogenic satellite cells can be isolated from a number of tissues including skeletal muscle (Blau \& Webster, 1981; Chen et al., 2005; Gaster et al., 2001a; McAinch \& CameronSmith, 2009). When cultured in specific conditions, quiescent satellite cells isolated from donor skeletal muscle can be stimulated to re-enter the cell cycle and proliferate before being terminally differentiated to recapitulate the phenotype of skeletal muscle from the donor.

As such primary skeletal muscle myotubes have multiple research applications including but not limited to; 1) the study of the effects of myopathies and systemic metabolic diseases on skeletal muscle function, 2) tissue regeneration and renewal for tissue engineering purposes, 3) gene therapy and 4) drug screening (Berggren et al., 2007; Chen et al., 2005; Kessler et al., 1996; Loro et al., 2010; McAinch \& Cameron-Smith, 2009; McAinch et al., 2006a; McAinch et al., 2006b; McAinch et al., 2007; Stern-Straeter et al., 2008).

The following sections outline the process of culturing human primary myotubes from their isolation from muscle biopsies to their growth and maintenance in culture and finally a brief look at their current and future applications. At this point we are compelled to mention that methodological variations arise at almost every stage of primary myotube culture, especially in regards to medium composition and the differentiation protocol. Whilst we endeavour to consider the differences in protocols and the implications of these, we primarily report the established methods of our laboratory. Therefore some optimisation may be necessary on behalf of the end user where experimental outcomes differ significantly.

\section{The muscle biopsy}

A number of techniques can be used to obtain a skeletal muscle biopsy including needle biopsy and surgical excision (Dietrichson et al., 1987; Tarnopolsky et al., 2011). Successful isolation of myogenic satellite cells can be undertaken from small samples of muscle biopsies ranging in size from 50-100 mg (wet weight) (McAinch et al., 2007). This suggests that the typical muscle yield from suction-enhanced needle biopsies is sufficient to culture viable primary myotubes (Melendez et al., 2007; Tarnopolsky et al., 2011). The use of needle biopsy has additional benefits in the relative ease of obtaining muscle biopsies, enabling sampling from a number of accessible skeletal muscles with only the use of local anaesthetic (Dietrichson et al., 1987). The suction-enhanced method described by Tarnopolsky et al., (2011) is described briefly as follows.

The area from which the muscle biopsy is to be obtained is sterilised and the skin and subcutaneous tissue is numbed with a local anaesthetic. A small stab incision (4-5 $\mathrm{mm})$ is made in the skin at the biopsy site. With the aperture closed, the biopsy needle is advanced through this incision to penetrate at least $1 \mathrm{~cm}$ beyond the fascia. This motion will be associated with the sensation of deep pressure within the muscle. Once the needle is in position within the muscle, the aperture is opened, and if using a suction enhanced 
technique, suction is applied using a sterile $60 \mathrm{ml}$ syringe (approximately $20 \mathrm{ml}$ per sample). It is important to note that the equipment used by these authors is modified to accommodate the suction procedure. However, the biopsy size is significantly increased by using suction compared to no suction (approximately $125 \mathrm{mg}$ compared to $35 \mathrm{mg}$, respectively. However significant variation in muscle biopsy size exists). The needle is then closed to isolate the muscle biopsy. The needle can then be rotated to obtain another muscle sample as above. The authors describe taking up to 3 samples in quick succession in the one biopsy to obtain adequate muscle sample and is associated with minimum discomfort. The needle is removed using a twisting motion during withdrawal. Pressure is applied to the skin incision and it is closed with a single suture or a tape closure (although a suture may be associated with a lesser degree of scarring) and then pressure is reapplied for 10-15 minutes often with concomitant icing. It is then important the area be kept clean by the subject in the period following the procedure. If closed with a suture, the suture is removed 6 days after the biopsy procedure.

Alternately, skeletal muscle samples can be obtained by open biopsies during surgical procedures. This has the benefits of enabling visualisation of the muscle extract prior to excision and allows for an increase in extract size and/or more controlled sample size in comparison to needle biopsy techniques (Derry et al., 2009; Edwards et al., 1983). In these instances patients are usually under general anaesthetic and a muscle sample is taken from a pre-existing surgical incision, removing the need for an additional surgical incision and superficial trauma. Despite this, it is typically accepted that the needle biopsy procedure presents a more efficient means of obtaining a muscle biopsy (Derry et al., 2009; Edwards et al., 1983).

In our hands, skeletal muscle extracts are obtained from patients undergoing routine bariatric surgery for obesity or obesity and type 2 diabetes mellitus by the attending surgeon. In brief, patients undergo a 12-18 hour fast prior to surgery. They are anaesthetised via short acting propofol and maintained via a volatile anaesthetic mixture of fentanyl and rocuronium. Skeletal muscle extracts are obtained via surgical excision from the rectus abdominis muscle by the attending surgeon (McAinch et al., 2007). Skeletal muscle samples extracted from donors to be used for cell culture are trimmed of any visible fat or connective tissue and approximately $50 \mathrm{mg}$ of the muscle biopsy is suspended in serum-free alpha minimum essential media (Gibco, distributed by Invitrogen, Carlsbad, CA). These samples are immediately placed on ice for transportation and undergo no further processing prior to satellite cell isolation. Muscle samples stored in cell culture medium can be maintained at 4 ${ }^{\circ} \mathrm{C}$ for up to 24 hours prior to isolation of the satellite cell population with minimal adverse effects on cellular yield and viability (Blau \& Webster, 1981).

\section{Tissue culture methods}

\subsection{Isolation of myogenic satellite cells}

The myogenic satellite cell population of skeletal muscle fibres was first characterised by Mauro in 1961. This study correctly identified and proposed satellite cells to be important in muscle regeneration and growth (Mauro, 1961). Degenerative myopathies or muscle injury stimulates quiescent satellite cells to re-enter the cell cycle (Charge \& Rudnicki, 2004). Active satellite cells proliferate rapidly promoting muscle regeneration. Therefore controlled 
growth of satellite cells is seen to be favourable in the treatment of myopathies and in tissue engineering processes.

Here we describe the process of isolation of these myogenic satellite cells from skeletal muscle extracts which is modified from the methods of Blau \& Webster (1981). These methods have been adapted by our laboratory in accordance with optimisation by Gaster et al., (2001a). All processing of skeletal muscle extracts for cell culture should be carried out in a sterile isolated environment, free of biological contaminants. Accordingly, biological safety cabinets should be sterilised under UV light for 20 minutes and cleaned with $70 \%$ ethanol prior to use to minimise the risk of contaminating the sample with extraneous cell types. All equipment used must be sterilised.

Satellite cells are isolated from skeletal muscle extracts of 50-100 mg through enzymatic dissociated in $0.05 \%$ trypsin-EDTA (Gibco, distributed by Invitrogen, Carlsbad, CA) via a series of incubations. Skeletal muscle extracts are washed twice in approximately $5 \mathrm{ml}$ of alpha minimum essential medium and then washed 3 times in approximately $5 \mathrm{ml}$ of ice-cold $1 \mathrm{x}$ Dulbecco's phosphate buffered saline (Gibco, distributed by Invitrogen, Carlsbad, CA). Any remaining connective tissue is removed at this stage. Subsequently, the skeletal muscle extract is manually homogenised in $3 \mathrm{ml}$ of $0.05 \%$ trypsin-EDTA in a tissue culture dish using a sterile scalpel. The desired size for muscle fragments is less than $1 \mathrm{~mm}^{3}$ (Blau \& Webster, 1981). The resultant homogenate is then combined with an additional $12 \mathrm{ml}$ of $0.05 \%$ trypsin-EDTA in a sterile vial, sealed and agitated on an orbital mixer for 20 minutes. Thereafter, the supernatant is aspirated and combined with $5 \mathrm{ml}$ of foetal bovine serum in a $50 \mathrm{ml}$ falcon tube before being placed on ice. Care must be taken at this step to ensure the finely homogenised muscle extract is not aspirated with the supernatant. An additional $15 \mathrm{ml}$ of $0.05 \%$ trypsin-EDTA is added to the extract and again agitated as specified above for 20 minutes. The supernatant is combined with the initial yield in the $5 \mathrm{ml}$ of foetal bovine serum. Three repetitions of this process are necessary to fully dissociate the muscle fibres. The supernatant (trypsin and foetal bovine serum mixture) is next filtered through a BD Falcon ${ }^{\mathrm{TM}} 100-\mu \mathrm{m}$ nylon cell strainer (BD Biosciences, Bedford, MA). To isolate the cellular fraction of the supernatant, it is transferred to a sterile $50 \mathrm{ml}$ falcon tube and is centrifuged for 7 minutes at $0.5 \times \mathrm{g}$. The resulting pellet of cells will localise at the bottom of the tube and appear reddish-brown in colour. The cellular fraction is gently resuspended in $5 \mathrm{ml}$ of growth medium (alpha minimum essential medium supplemented with $10 \%$ foetal bovine serum (v/v), $0.5 \%$ penicillin streptomycin (v/v) (Gibco, distributed by Invitrogen, Carlsbad, CA) and 0.5\% amphotericin B (v/v) (Sigma-Aldrich, St Louis, MO)) via repeated pipette mixing.

Following the above protocol should yield approximately $5 \times 10^{3}$ viable, proliferating satellite cells from a $0.1 \mathrm{~cm}^{3}$ muscle sample (Blau \& Webster, 1981).

\subsection{Myoblast culture and maintenance}

As the cellular population isolated does not consist solely of myogenic satellite cells, the cell suspension is initially cultured on an uncoated $25 \mathrm{~cm}^{2}$ tissue culture flask (Greiner Bio-One, Monroe, NC) for 20 minutes in a controlled humidified environment of $37^{\circ} \mathrm{C}$ and $5 \%$ carbon dioxide. This increases the satellite cell content of the cultured sample and minimises contamination by fibroblasts which preferentially adhere to the surface of the tissue culture vessel. Gaster et al., (2001a) provide evidence of increased sample purity after pre-plating 
showing a time dependent increase in satellite cell fraction. However, increased duration of pre-plating is associated with a greater total loss of satellite cells and therefore we choose a duration of 20 minutes. After the 20 minute incubation period, gently aspirate the cell suspension taking care not to disturb the base of the flask to which the majority of fibroblasts will have attached. This flask is then discarded. The aspirated cell suspension is then seeded onto a $25 \mathrm{~cm}^{2}$ flask coated with an extracellular matrix (Geltrex ${ }^{\mathrm{TM}}$ Reduced Growth Factor Basement Membrane Matrix; Invitrogen, Carlsbad, CA; allow extracellular matrix coating to dry in a sterile environment before seeding cells) to simulate the basement membrane under endogenous conditions. Extracellular matrices containing laminin and collagen IV, such as Geltrex ${ }^{\mathrm{TM}}$, have been shown to promote preferential satellite cells adhesion over fibroblast adhesion to enhance the satellite cell fractional content (Kuhl et al., 1986). Cells are then incubated in a cell culture $\mathrm{CO}_{2}$ incubator in the conditions described above. Viable cells will adhere to the coated base of the tissue culture flask over the next 24 hours. These cells are considered to be at passage 1 . The isolation and initial culturing of the myogenic satellite cells is depicted in figure 1.

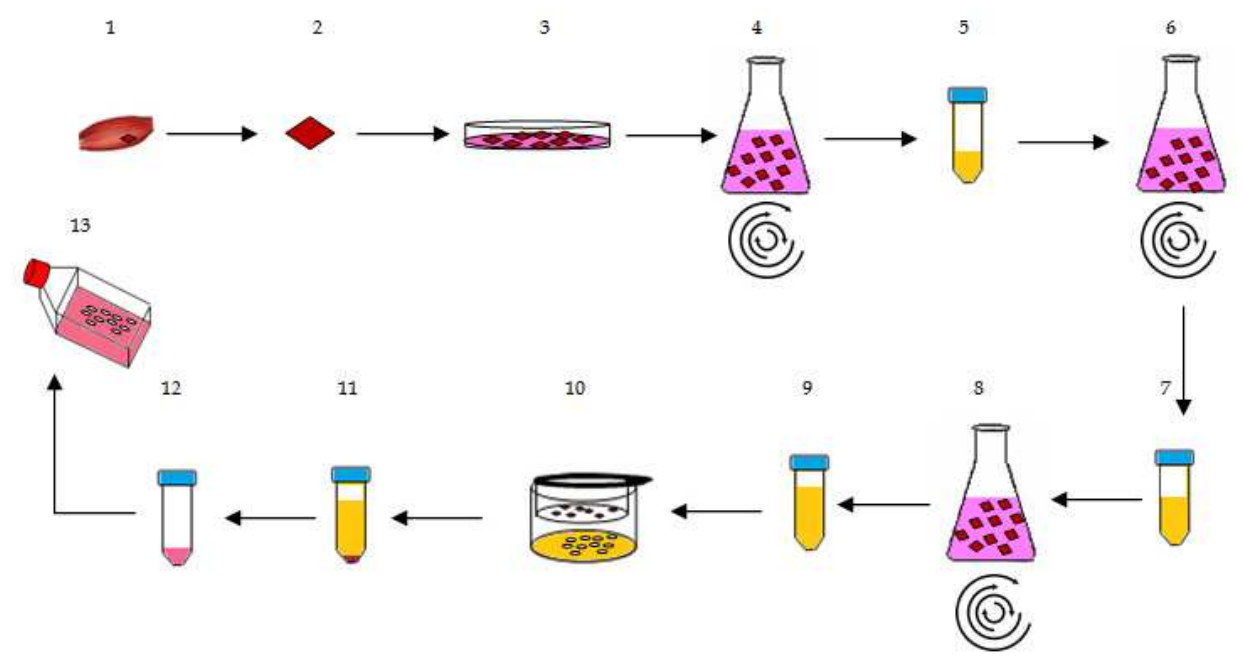

Fig. 1. Schematic representation of the isolation and initial culturing of myogenic satellite cells. 1, site of muscle biopsy is chosen; 2 , biopsy extracted; 3 , muscle biopsy is manually minced in trypsin-EDTA; 4 , first enzymatic dissociated in trypsin under constant agitation; 5 , supernatant is combined with foetal bovine serum; 6 , second enzymatic dissociated in trypsin under constant agitation; 7, supernatant is combined with foetal bovine serum; 8 , third enzymatic dissociated in trypsin under constant agitation; 9, supernatant is combined with foetal bovine serum; 10, supernatant/foetal bovine serum solution is filtered; 11, cellular fraction is pelleted via centrifugation, 12, cellular pellet is resuspended in growth medium; 13, isolated cells are seeded into a $25 \mathrm{~cm}^{2}$ tissue culture flask for pre-plating and then transferred to an extracellular matrix coated flask and maintained at $37^{\circ} \mathrm{C}$ and $5 \%$ carbon dioxide.

24 hours after the initial seeding, the cells are washed twice with 1x phosphate buffered saline to remove cellular debris along with non-adherent and non-viable cells. Thereafter, 
growth medium $(5 \mathrm{ml})$ should be refreshed every other day subsequent to a washing step with approximately $5 \mathrm{ml} 1 \mathrm{x}$ phosphate buffer saline. Continue to maintain the growth of the cells until approximately $70 \%$ confluence is reached. This may take 2-3 weeks and therefore it is essential to monitor cell growth to ensure they do not become over-confluent within this period. If myoblastic cells become over-confluent, spontaneous differentiation to mature myotubes will occur and the mitogenic properties of the cells will be lost. At $70 \%$ confluency, dissociate the cells from the flask through the addition of $1.5 \mathrm{ml}$ of $0.05 \%$ trypsin-EDTA and subsequent incubation at $37^{\circ} \mathrm{C}, 5 \% \mathrm{CO}_{2}$ for 3 minutes. At this point cells will appear suspended in the media and therefore successful dissociation can be confirmed via microscopic examination. Next, inactivate the trypsin with $3 \mathrm{ml}$ of growth medium, gently ejected over the base of the flask to remove any remaining adherent cells. Isolate the cellular fraction through centrifugation ( 5 minutes at $0.4 \times \mathrm{g}$ ) and resuspend the cell pellet in $50 \mathrm{ml}$ growth medium. Gently mix to ensure homogenous cell distribution and then seed onto five extracellular matrix coated $75 \mathrm{~cm}^{2}$ cell culture flasks. These cells are designated to be at passage 2. Cells are again grown to approximately $70 \%$ confluent following the same procedure as describe for cells at passage 1, before dissociation and isolation via centrifugation. At this point we usually cryopreserve four of the $75 \mathrm{~cm}^{2}$ flasks and maintain one for continued growth to passage 3 . Cryopreservation enables establishment of a number of stored cell vials for future experimental use to assist in the investigation of your chosen research field. The process of cryopreservation is given in section 4.2.1. The remaining flask is passaged once more as above and seeded onto ten extracellular matrix coated $75 \mathrm{~cm}^{2}$ flasks (split ratio 1:10). At 70\% confluence cells are trypsinised and isolated via centrifugation ( 5 minutes at $0.4 \times \mathrm{g}$ ) and can at this point be cryopreserved.

It is common throughout this process for cell lines isolated from different individuals to exhibit a distinct growth pattern which may be reflected in considerably longer or shorter times taken to reach confluence. Moreover, myoblasts may initially exhibit slow growth patterns, however once maintained in culture for a number of days, growth rates may increase rapidly. Therefore, regularly observing the confluence of the myoblasts is critical to ensure that passaging takes place at the appropriate confluence. Similarly to the dissociable growth patterns of myotubes derived from different individuals, myotubes may also differ in appearance depending on the donor. This can complicate the determination of confluence and therefore each cell line needs to be judged on an individual basis relative to area for growth.

\subsubsection{Cryopreservation of myoblastic cells}

Cryopreservation of cell stocks is an important practice in any laboratory as it helps to protect against loss of cell lines through bacterial or fungal contamination. Furthermore, as primary cell lines can be passaged finitely before becoming senescent, cryopreservation of cell lines ensures that cell stocks are maintained. It is important that viable cells are chosen for cryopreservation and that the cells are not depleted of myogenic properties due to becoming over-confluent at an earlier passage.

The cryopreservation method used in our laboratory for human primary myoblasts are described herein. Using this method we have established stocks of a large number of viable cell lines derived from muscle extracts. One $75 \mathrm{~cm}^{2}$ flask at $70 \%$ confluent provides sufficient 
cells for distribution to two cryotubes. Thus, the four flasks from passage 2 can be frozendown in eight cryotubes whilst the ten flasks from cells at passage 3 enable twenty cryotubes to be frozen. This facilitates the rapid expansion of stores of subcultures. In order to ensure consistency between studies, we cryopreserve all cells prior to experimental use. Cells are cryopreserved in a solution containing $25 \%$ growth medium (v/v), $25 \%$ foetal bovine serum (v/v) and 50\% filter sterilised freezing medium. Freezing medium can be made through the addition of $10 \%$ dimethyl sulfoxide (v/v; Sigma-Aldrich, St Louis MO) to standard growth medium (as defined in section 4.1). Dimethyl sulfoxide is a freezing agent which acts to reduce the freezing point of the medium to facilitate gradual cryopreservation and prevents ice crystals forming during freezing and lysing the cells. Dimethyl sulfoxide is photosensitive and therefore it is important to protect the freezing medium from light at all stages. Freezing medium is then filter sterilised prior to use though a $0.2-\mu \mathrm{m}$ nylon cell filter. Dissociated cells and isolate the cellular fraction via centrifugation as outlined in section 4.2 and then resuspend the pellet in growth medium (25\% of total volume). Add to this the foetal bovine serum ( $25 \%$ of total volume). Add the pre-made freezing medium to the cell solution (50\% of total volume) and gently mix. Aliquot $1 \mathrm{ml}$ of this solution into each labelled cryotube. The specific volumes to be used depends on the number of flasks to be cryopreserved, however as a guide for two $75 \mathrm{~cm}^{2}$ flask use $1 \mathrm{ml}$ of growth medium, $1 \mathrm{ml}$ of foetal bovine serum and $2 \mathrm{ml}$ of freezing medium. To minimise cell death, cells are incrementally frozen at $-20^{\circ} \mathrm{C}$ for 30 minutes and then enclosed in a foam box for freezing at $-80^{\circ} \mathrm{C}$ overnight, before finally being stored in liquid nitrogen until required. Alternatively use a cryopreservation freezing container such as "Mr. Frosty" (Nalgene ${ }^{\circledR}$ Labware as part of Thermo Fisher Scientific, New York) which results in a controlled decrease in temperature of $1^{\circ} \mathrm{C}$ per minute. Gradually decreasing the temperature during the freezing process aids in preserving cell viability and hence is critical to successful cryopreservation of a viable myoblastic cell population. However, it is also important to note that dimethyl sulfoxide is cytotoxic and therefore once cells are combined with the freezing medium it is important to progress to the freezing stage as rapidly as possible.

Conversely, the thawing procedure must take place as rapidly as possible again due to the toxic nature of dimethyl sulfoxide. We recommend immersing the bottom two thirds of the cryotube in a waterbath heated to $37^{\circ} \mathrm{C}$. Take care not to let the water reach the level of the lid as this will increase the risk of contamination of the subculture. When partially thawed the sample should be removed from the waterbath and rapidly combined with approximately 1-2 $\mathrm{ml}$ of growth medium to dilute the dimethyl sulfoxide and gently pipette mixed to facilitate thawing. Once fully thawed, combine the cell solution with $9 \mathrm{ml}$ of growth medium and centrifuge at $0.4 \times \mathrm{g}$ for 5 minutes to pellet the cellular fraction. Pour off the growth medium to remove the dimethyl sulfoxide and gently resuspend the pellet in growth medium. Myoblasts can then be seeded onto $75 \mathrm{~cm}^{2}$ or $175 \mathrm{~cm}^{2}$ tissue culture flasks, depending on the volume of cells required for experimentation. As a rough guide one 75 $\mathrm{cm}^{2}$ tissue culture flask at $80 \%$ confluence provides adequate cells for ten 6-well tissue culture plates or ten $100 \mathrm{~mm}$ tissue culture dishes. We recommend that experimentation be conducted at passage 4 or 5 to avoid senescence. For our purposes cells cryopreserved at passage 3 will be at passage 4 when thawed and subcultured. Thus at $80 \%$ confluence these cells must be seeded onto the appropriate vessel for differentiation and experimentation at passage 5. Therefore, when thawing cells it is important to be aware of the volume of cells that will be required to complete the study. 


\subsection{Myotube formation}

The process of myoblast fusion is critical to the development of mature multinucleate skeletal muscle myotubes. During the process of myoblast differentiation, the myogenic cells exit the cell cycle and mitotic activity ceases (Linkhart et al., 1981; Yaffe, 1968). Myogenic commitment is under the synergistic regulation of a vast number of myogenic promoters (including MyoD, myogenin, Myf5, myogenic regulatory factor 4, myocyte specific enhancement factor 2) and inhibitors (including ID, Msx1, Twist and BMP-4) (reviewed by Brand-Saberi \& Christ, 1999; Charge \& Rudnicki, 2004). Table 1 further highlights the expression patterns of myogenic markers associated with different stages of myogenic development.

Extracellular factors also mediate myotube differentiation. Such factors include the cell-cell interactions and proximity and cellular interactions with the extracellular matrix. Concordant with this, studies by Osses \& Brandan (2002) and Langen et al. (2003) show that the extracellular matrix enhances myogenic differentiation of clonal $\mathrm{C}_{2} \mathrm{C}_{12}$ myoblasts. In vitro, protocols used to induce myoblast fusion vary greatly between studies. This has the potential to confound the comparison of results between studies. Predominately, differentiation protocols vary in the duration and the composition of media used to induce myogenic differentiation.

\begin{tabular}{llll}
\hline Myogenic stage & $\begin{array}{l}\text { Increase } \\
\text { expression }\end{array}$ & $\begin{array}{l}\text { Decreased } \\
\text { expression }\end{array}$ & $\begin{array}{l}\text { Variable } \\
\text { expression }\end{array}$ \\
\hline $\begin{array}{l}\text { Muscle derived stem } \\
\text { cell }\end{array}$ & Sca-1 & CD34 \\
& Bcl-2 & \\
\hline All MRFs & & m-cadherin \\
Quiescent Satellite cell & c-MET & Myf5 \\
& Truncated CD34 & MyoD \\
& Pax7 & Myogenin \\
\hline Myogenic precursor & m-cadherin & \\
cell & c-Met & \\
& Full length CD34 & & \\
& Myf5 & & \\
& MyoD & & \\
\hline Terminal & Desmin & & \\
differentiation & Myogenin & CD34 & \\
& MRF4 & Pax7 & \\
\hline
\end{tabular}

Adapted from review by Deasy et al., (2001)

MRF; Myogenic regulatory factor.

Table 1. Expression of myogenic markers at different stages of myotube formation.

Myoblast fusion and subsequent myotube formation has been reported to occur over a period of 4-8 days (Gaster et al., 2001b). In our hands, a differentiation protocol of 4 days is 
sufficient to induce myoblasts elongation and fusion to produce multinucleate myotubes. The results of Gaster et al., (2001b) substantiate this, showing that on the day after culture conditions were changed to induce differentiation, myoblast fusion to form myotubes had begun and there was an increase in creatine kinase activity and fast myosin heavy chain content up until day 4 when these markers began to decline. This study also reported the presence of developing myofibrils and cross-striations at day 8 of differentiation (Gaster et al., 2001b), however no data is reported evaluating these parameters before this time. Therefore, it is hard to compare the presence of the developing contractile apparatus with functional measures such as creatine kinase activity and fast myosin heavy chain content which were seen to decline from day 4 onwards. Contrary to this Stern-Straeter et al., (2008) observed increased expression of myogenic genes from day 4 of differentiation but peaked at day 16. Creatine kinase activity in this study was also seen to peak at day 16 (SternStraeter et al., 2008). These results suggest a longer differentiation period may facilitate further maturation of the myotube cultures and therefore provide a more physiological representation of skeletal muscle. However, longer durations of differentiation can lead to myotube detachment and subsequent cellular death. Moreover, it has been shown in rats that the source of skeletal muscle biopsy (that is, soleus compared to extensor digitorum longus) affected the rate at which the isolated cells differentiated (Lagord et al., 1998). This suggests that the source of muscle will alter the myogenic properties of the derived human primary myotubes.

Aside from variations in the duration of culturing, myoblast fusion can be induced under a number of conditions such as a reduction in sera concentration and substitution of foetal bovine serum with horse serum, which contains less growth factors (Gaster et al., 2001a; Gaster et al., 2001b; Linkhart et al., 1981; McAinch et al., 2007). Further, addition of growth factors (vitronectin, B27 supplement, basic fibroblast growth factor, cardiotropin-1, brainderived neitrophic factor, glial derived neurotrophic factor and neutrophin 3 and 4) (Das et al., 2009) and provision of soluble basement membrane in the absence of additional growth factors and serum (Langen et al., 2003) can also be used to promote differentiation.

In view of these variations, some contention exists as to the optimal protocol for myoblast differentiation. Accordingly, the differentiation process may need to be optimised by the end user for their specific needs. Differentiation can be confirmed via a number of different measures including analysis of sarcomere formation, creatine kinase activity, myosin heavy chain and alpha actin content and expression of myogenic markers MYoD (up-regulated in earlier stages of differentiation), myogenin, desmin, and myogenic regulatory factor 4 (Blau \& Webster, 1981; Stern-Straeter et al., 2008; Stern-Straeter et al., 2007). Such analyses enable individual optimisation of the differentiation process to suit the demands of specific studies.

For our purposes the optimised differentiation protocol is as follows. At approximately 70$80 \%$ confluent, cells which have previously been seeded onto extracellular matrix coated tissue culture vessels are washed in 1x phosphate buffered saline. A simple substitution of $10 \%$ foetal bovine serum for $2 \%$ horse serum is made in the replacement medium. All other components remain the same as for the growth medium (that is, differentiation media contains $2 \%$ horse serum (v/v), $0.5 \%$ penicillin streptomycin $(\mathrm{v} / \mathrm{v})$ and $0.5 \%$ amphotericin B $(\mathrm{v} / \mathrm{v}))$. Cells are washed and differentiation media is changed every other day until day 4 is reached. When visualised microscopically cells will appear elongated and fusion will be evident. At this point myotubes are ready for experimentation. 


\section{Experimentation}

At the conclusion of the optimised differentiation protocol, myotubes are ready for experimental purposes. However, the specific protocol used in the final stages of myotube culturing is dependent on the end use of the myotubes. That is, the way the myotubes are subcultured and subsequently lysed will depend on the experiment to be conducted. Here we will briefly examine some of the key considerations in designing experiments for analysis of different metabolic parameters.

\section{1 mRNA analysis of genetic markers}

The analysis of gene expression provides an invaluable source of information regarding changes in the expression of key regulatory genes. Gene expression often provides the basis for additional studies aimed at assessing the effects of experimental interventions on cellular signalling. The growth of human primary myotubes for gene expression purposes has several subtle differences to that of other outcomes. Myotubes grown for the analysis of messenger RNA abundance are typically grown in 6-well tissue culture plates (Greiner BioOne, Monroe, NC) as decreased cell volume is typically needed for successful RNA extraction. Given the lower area for growth (approximately $9.6 \mathrm{~cm}^{2}$ per well) confluence is often reached in a shorter period and therefore it is important to regularly check confluence to ensure differentiation is conducted at $70-80 \%$ confluence. Being over-confluent will risk the cells detaching during the experimental period. Subsequent to experimentation, the next key consideration is the process by which the cells are to be lysed. The experimental treatments should be ceased by rapidly washing each well 3 times in approximately $2 \mathrm{ml}$ of ice-cold 1x phosphate buffered saline. Myotubes should be placed immediately on ice to inhibit RNase activity after the third wash and then rapidly lysed. We find the lysis of cells with TRIzol@ reagent (Invitrogen, Carlsbad, CA) is highly efficient and provide a high yield of quality RNA (as determined spectrophometrically). RNA is a particularly unstable molecule and it is important to ensure that the sample is not contaminated with RNases during the extraction procedure. TRIzol ${ }^{\circledR}$ reagent acts to solubilise cellular membranes and debris whilst inhibiting RNase activity and maintains RNA integrity (Santella, 2006). However, due to the corrosive TRIzol® (including the vapour phases) cells should be transferred on ice to an RNA designated fumehood prior to the addition of this reagent. Using filtered pipette tips add $800 \mu \mathrm{l}$ of TRIzol@ to each well. Gentle agitate the TRIzol@ to ensure that the entire surface of the well is covered and then repeatedly eject the TRIzol® over the base of the well to ensure myotubes are lysed. Transfer cellular lysates to a labelled tube. At this point the cellular lysates can be stored at $-80^{\circ} \mathrm{C}$ until ready to continue with the RNA extraction.

Total cellular RNA is then extracted through the addition of $200 \mu 1$ of chloroform (Sigma Aldrich, St Louis, MO) to the cellular lysates. Mix via short vortex and then allow to sit on ice for 5 minutes. Centrifuge the TRIzol®/chloroform for 15 minutes at $16,000 \times \mathrm{g}$ to separate the phases. Three distinct phases should be visible; a bottom phase containing the TRIzol ${ }^{\circledR}$ and cellular debris, a thin opaque interphase and a clear RNA containing supernatant. If the separation of phases does not occur, re-vortex the tube and allow to sit on ice before centrifuging again as above. The RNA containing supernatant is then aspirated into a fresh tube containing an equal volume of isopropanol to supernatant (approximately 
$600 \mu \mathrm{l}$; Sigma Aldrich, St Louis, MO) and $10 \mu \mathrm{l}$ of $5 \mathrm{M}$ sodium chloride (Ajax Finechem, Seven Hills, Australia). Care must be taken not to contaminate the RNA sample with the interphase and therefore it is recommended that $80 \%$ of the supernatant volume be aspirated. At this point incubate the samples at $-20^{\circ} \mathrm{C}$ for a minimum of 2 hours (can be left overnight) to precipitate the RNA pellet. Subsequent to the incubation period, centrifuge the samples at $16,000 \times \mathrm{g}$ for 20 minutes to isolate the pellet. Take care to orient all tubes in the same manner to enhance the ease of RNA extraction, as the RNA pellet may be small and difficult to visualise. Aspirate the isopropanol/sodium chloride solution taking care not to aspirate the RNA pellet. Wash the pellet once with $400 \mu 1$ of $75 \%$ molecular grade ethanol (Sigma Aldrich, St Louis, MO) and centrifuge for 8 minutes at 8,000 x g. Again aspirate the ethanol taking care not to aspirate the RNA pellet and then allow the pellet to air-dry for 5-8 minutes on ice. Resuspend the RNA pellet in $5 \mu$ l of sterile diethylpyrocarbonate treated water (Invitrogen, Carlsbad, CA). The resuspension of the pellet can be enhanced by heating the diethylpryocarbonate treated water to $65^{\circ} \mathrm{C}$. Transfer $1 \mu \mathrm{l}$ of RNA to a fresh tube containing $19 \mu \mathrm{l}$ of diethylpyrocarbonate treated water for spectrophotometric determination of RNA content at $260 \mathrm{~nm}$ and $280 \mathrm{~nm}$. RNA purity can be determined from OD260/OD280 ratio. Samples with an OD260:OD280 ratio of $1.9-2.1$ can be considered of high quality and relatively free of contaminates (Santella, 2006). RNA samples should be stored at $-80^{\circ} \mathrm{C}$ until required.

RNA can then be reverse transcribed to complementary DNA via the use of such kits as the iScript cDNA synthesis kit (Bio-Rad Laboratories, Hercules, CA). Resultant complementary DNA can then analysed for messenger RNA expression of genes of interest by such techniques as 'real-time' polymerase chain reaction (Heid et al., 1996). Data from 'real-time' polymerase chain reaction can be analysed by either absolute quantification or relative quantification (Livak \& Schmittgen, 2001). Absolute quantification determines the input copy number of the gene of interest usually against known standards, whilst relative quantification enables determination of the expression of the gene of interest relative to a reference gene (Livak \& Schmittgen, 2001).

\subsection{Protein}

The growth of myotubes for analysis of protein markers requires a greater cell density than is required for analysis of gene expression. Accordingly, when growing for analysis of protein expression, myotubes should be subcultured and grown to confluence on $100 \mathrm{~mm}$ tissue culture dishes (Greiner Bio-One, Monroe, NC) coated with extracellular matrix prior to differentiation. As for messenger RNA analysis cells destined for protein expression studies need to be differentiated at approximately $70-80 \%$ confluence to ensure an adequate yield. To stop experimental treatments cells should be washed twice with ice-cold $1 x$ phosphate buffered saline. To avoid dilution of the protein fraction it is important to remove excess phosphate buffered saline with either suction or transfer pipettes. When lysing cells for protein expression the addition of a protease inhibitor to the lysis buffer is necessary to inhibit proteolytic protein degradation. For muscle cultures we find that an immunoprecipitation lysis buffer (10 mM Tris pH 7.5, $5 \mathrm{mM}$ EDTA, $150 \mathrm{mM} \mathrm{NaCl}, 1 \% \mathrm{NP}-$ 40) containing complete mini protease inhibitor cocktail tablet per $10 \mathrm{ml}$ working stock (Roche Diagnostics, Indianapolis, IN) is suitable in lysing cells for protein extraction. 
Adherent skeletal muscle myotubes are lysed using $100 \mu \mathrm{l}$ of immunoprecipitation lysis buffer and complete mini-protease inhibitor cocktail tablet. Mechanically detached adherent cells from the base of the $100 \mathrm{~mm}$ cell culture dish with a cell scraper (Greiner Bio-One, Monroe, NC). To proceed with protein extraction, centrifuge the cellular lysate at $17,000 \times \mathrm{g}$ for 4 minutes. Carefully aspirate the supernatant, aliquot and store at $-80{ }^{\circ} \mathrm{C}$. Freeze-thaw cycles should be avoided.

Protein abundance can then be quantified against known albumin standards with a working range of $20-2000 \mu \mathrm{g} / \mathrm{ml}$ in accordance with the assay microplate procedure using a Pierce Bicinchoninic Acid kit (Pierce Biotechnology distributed by Thermo Fisher Scientific, Scoresby, Australia) at $562 \mathrm{~nm}$. We have previously found that the protein content from a single $100 \mathrm{~mm}$ tissue culture dish is low and in order to have sufficient protein to measure multiple markers it may be necessary to have a number of replicates for each experimental condition which can be combined to increase the overall protein concentration. If this is the case up to four $100 \mathrm{~mm}$ dishes can be lysed using $100 \mu \mathrm{l}$ of lysis buffer transferred from plate to plate along with the cellular lysates. This helps to reduce sample dilution with the lysis buffer.

\subsection{Glucose and fatty acid uptake}

Aberrant glucose and fatty acid metabolism is observed in human primary myotubes isolated from individuals with obesity and type 2 diabetes mellitus compared to control (Bell et al., 2010; Mott et al., 2000; Thompson et al., 1996). Therefore, determination of glucose and fatty acid uptake in these cells can be a useful tool in screening new pharmacological agents aimed at ameliorating perturbed substrate metabolism. The process described below outlines the key methodological considerations for growing human primary myotubes for glucose and fatty acid uptake assays.

\subsubsection{Glucose uptake}

Prior to differentiation, skeletal muscle myotubes should be grown to approximately $70 \%$ confluence in 12 well tissue culture plates. At confluence, differentiation should be undertaken for 4 days. Previous results indicate that basal glucose uptake decreases upon myoblast fusion (Klip et al., 1984; Mitsumoto et al., 1991). In contrast insulin-stimulated glucose uptake increases subsequent to myoblast fusion particularly in the serum deprived L6 myotubes (Klip et al., 1984; Mitsumoto et al., 1991). Therefore for this particular assay we recommend a differentiation period of 4 days however this may need to be optimised depending on the specific outcome of the study. The protocol for measuring glucose uptake is adapted from that of Ciaraldi et al., (1995).

At confluence, myotubes are pre-incubated in serum free alpha-minimum essential medium for 4 hours and subsequently washed three times in uptake buffer $(150 \mathrm{mM} \mathrm{NaCl}, 5 \mathrm{mM}$ $\mathrm{KCL}, 1.2 \mathrm{mM} \mathrm{MgSO}_{4}, 2.5 \mathrm{mM} \mathrm{NaH}_{2} \mathrm{PO}_{4}, 1.2 \mathrm{mM} \mathrm{CaCl}_{2}, 10 \mathrm{mM}$ HEPES, 0.1\% bovine serum albumin, pH 7.4). Myotubes should then be incubated with the compound of interest in $1 \mathrm{ml}$ of uptake buffer for the given time period. Initiate the glucose uptake reaction through the addition of radiolabelled glucose $\left(2-\left[{ }^{3} \mathrm{H}\right]\right.$-deoxy-D-glucose) at $1 \mu \mathrm{Ci} / \mathrm{ml}$ and 2-deoxy-Dglucose (Perkin Elmer, Waltham, MA) at $10 \mu \mathrm{M}$ per well and incubate at $37^{\circ} \mathrm{C}$ and $5 \% \mathrm{CO}_{2}$ for 15 minutes. Subsequently, aspirate the reaction buffer and rinse the myotubes four times 
rapidly with ice cold $1 x$ phosphate buffered saline to stop the reaction. Solubilise the myotubes with $500 \mu \mathrm{l}$ of $0.1 \mathrm{M}$ sodium hydroxide for 30 minutes at room temperature. This process can be enhanced by gentle agitation. The cellular lysates should then be divided with $400 \mu \mathrm{l}$ being combined with $4 \mathrm{ml}$ of scintillation fluid in scintillation vials for determination of incorporated radiolabelled glucose. The remainder of the lysates should be used to determine cellular protein content. Non-specific glucose uptake can be determined in the presence of cytochalasin B $(10 \mu \mathrm{M} / 1)$ to block glucose transporter mediated glucose uptake (Ceddia et al., 2005; Fletcher et al., 2000; Michael et al., 2001). Cytochalasin B has been shown to be a potent inhibitor of cellular glucose uptake (Kletzien et al., 1972). Nonspecific glucose uptake is subtracted from the total glucose uptake values and the net glucose uptake value is expressed relative to cellular protein content in picomoles of 2deoxy-glucose taken up by the myotubes per mg protein per minute.

\subsubsection{Fatty acid uptake}

The process of determining fatty acid uptake is similar to that of glucose uptake and accordingly, human primary myotubes should be grown and differentiated in the same manner. Differentiated myotubes should then be exposed to the experimental conditions. Fatty acid uptake can then be measured in the presence of $\left[1-{ }^{14} \mathrm{C}\right]$ palmitate (Perkin Elmer, Waltham, MA) and non-radiolabelled palmitate (Pimenta et al., 2008). In brief, the palmitate uptake is assayed through the addition of $0.2 \mu \mathrm{Ci} / \mathrm{ml}[1-14 \mathrm{C}]$ palmitate and $20 \mu \mathrm{M}$ nonlabelled palmitate (Fediuc et al., 2008) in serum free alpha-minimum essential medium for 4 minutes. Palmitate should be conjugated to fatty acid free bovine serum albumin at a molar ratio of 1 . Cells should be lysed in $500 \mu \mathrm{l}$ of $0.1 \mathrm{M} \mathrm{NaOH}$ for 30 minutes and palmitate uptake is determined relative to cellular protein content as above.

\subsection{Fatty acid oxidation}

In addition to determining substrate uptake it is also possible to determine the rate of fatty acid oxidation in human primary myotubes. This allows a more thorough assessment of cellular bioenergetics as corresponding results of enhanced uptake and oxidation may be indicative of improve metabolic function, whilst results of enhanced uptake but impaired oxidation may suggest that the intervention has elicited detrimental effects. Palmitate oxidation is determined from the production of radioactive ${ }^{14} \mathrm{CO}_{2}$ from $\left[1-{ }^{14} \mathrm{C}\right]$ palmitate. This outcome can be determined through measurements of radiolabelled $\mathrm{CO}_{2}$ or water with many variations existing in technique (Fediuc et al., 2006; Fediuc et al., 2008; Pathmaperuma et al., 2010; Petersen et al., 2005; Pimenta et al., 2008; Watt et al., 2006). One such method is described herein and has been adapted from previously described work of Petersen et al., (2005) in L6 skeletal muscle myotubes.

Myotubes should be grown in $100 \mathrm{~mm}$ tissue culture dishes until approximately $80 \%$ confluence at which point growth medium should be substituted for differentiation medium containing $2 \%$ horse serum. On day 4 of differentiation, pre-incubate the myotubes in serum free alpha minimum essential medium contain $0.1 \%$ bovine serum albumin for 2 hours. Following a washing step with $1 \mathrm{x}$ phosphate buffered saline, myotubes can be exposed to experimental conditions in alpha minimum essential medium containing $0.1 \%$ foetal bovine serum (v/v), $4 \%$ fatty acid free bovine serum albumin $(\mathrm{w} / \mathrm{v}), 0.1 \mathrm{mM}$ palmitate and $2 \mu \mathrm{Ci}$ of 
$[1-14 \mathrm{C}]$ palmitate with the respective experimental conditions. A 2 hour treatment period has been shown to be sufficient in determining fatty acid oxidation however the period of exposure can be modified to suit the experimental design and therefore should be optimised by the end user. Subsequent to experimental exposure $1 \mathrm{ml}$ of the incubation medium is added to a $20 \mathrm{ml}$ scintillation vial containing $1 \mathrm{ml}$ of $1 \mathrm{M} \mathrm{H}_{2} \mathrm{SO}_{4}$ and a $0.5 \mathrm{ml}$ microcentrifuge tube containing $1 \mathrm{M}$ benzethonium hydroxide to trap liberated ${ }^{14} \mathrm{CO}_{2}$ over a one hour period. The microcentrifuge tube containing the trapped ${ }^{14} \mathrm{CO}_{2}$ is then placed in a scintillation vial and counted to determine the rate of fatty acid oxidation.

\section{Future applications}

\subsection{Three-dimensional skeletal muscle tissue constructs}

Bioengineering of skeletal muscle constructs employs the use of myogenic progenitor cells and specialised scaffolding to form three-dimensional tissue constructs. Given the limited regenerative capacity of adult skeletal muscle, bioengineered skeletal muscle provides a therapeutically relevant method of reducing morbidity associated with various myopathies. Congruent with this, the long term goal of three-dimensional tissue culturing predominately centres around the provision of viable tissue transplants for regenerative purposes after acute injury or disease for instance the fabrication of three-dimensional cardiac muscle constructs. Like adult myotubes, mature cardiac myocytes are terminally differentiated cells and thus cannot regenerate subsequent to damage. Therefore the ultimate goal of bioengineered heart muscle supports myocardial regeneration after myocardial infarction, chronic heart failure or in the repair of congenital heart defects (Eschenhagen et al., 2002). This has the potential to reduce morbidity and mortality associated with cardiovascular diseases. Surgical tissue transplants are widely used in muscle regeneration after muscle injury, however muscle transplantation is associated with significant donor site morbidity, and loss of muscle volume and function (Bach et al., 2004). Implantable bioengineered skeletal muscle constructs remove the need for large muscle extracts from healthy donor tissue and thus pre-engineered tissue constructs provide an appealing treatment method for skeletal muscle pathologies. Bian \& Bursac (2008) propose distinct advantages associated with the use of bioengineered muscle constructs as being the ability to engineer constructs with architecture specific for the site of damage, the ability to precondition fabricated muscle for the specific mechanical and metabolic demands of the site and the administration of specific growth factors and hormones to support growth after implantation. However, despite these potential benefits, the field of bioengineered tissues is still in its relative infancy, with muscle constructs exhibiting morphological differences to native muscle with respect to the level of differentiation and organisation of the cell microstructure, making direct comparison with native muscle problematic (Baar, 2005).

The architectural, electrical and functional integrity of fabricated muscles must be similar to that of native muscle in order to compensate for structural and functional deficits within the endogenous muscle. Accordingly, the construct needs to be contractile, demonstrate electrophysiological stability, be flexible yet mechanically robust and have angiogenic potential. Currently, bioengineered muscle constructs are small in size with Huang et al., (2005) generating myooids of $177 \pm 10.5 \mu \mathrm{m}$ in diameter with the cross-sectional area of individual myotubes being only $10 \mu \mathrm{m}$. This is similar to results of Powell et al., (2002) who generated 
human bioartificial muscles with individual myotubes being less than $10 \mu \mathrm{M}$ in diameter. Furthermore, the current methods of generating muscle constructs result in myooids which exhibit significant deficits in force production compared to that of native muscle (Dennis et al., 2001). The absence of fibroblasts in constructs generated from $\mathrm{C}_{2} \mathrm{C}_{12}$ cells also resulted in a force deficit manifesting in a $35 \%$ reduction in peak twitch force after tetanic stimulation (Khodabukus \& Baar, 2009). The authors noted that addition of $3 \mathrm{~T} 3$ fibroblasts to $\mathrm{C}_{2} \mathrm{C}_{12}$ myotubes (ratio 1:5) prior to seeding attenuated this force deficit but lead to a $50 \%$ decrease in specific force. Taken together these results imply that further work needs to be done before bioengineered muscle constructs can be used for functional regeneration of human skeletal muscle. Nonetheless, in spite of the functional limitations, much can be gained through investigations of muscle formation using three-dimensional models of myotube growth (Bach et al., 2004).

Three-dimensional skeletal muscle tissue constructs provide a useful model for the study of muscle structure and function in physiological and pathophysiological states, drug screening and gene therapy despite current limitations in their fabrication (Bach et al., 2004; Vandenburgh, 2010; Vandenburgh et al., 2008). The use of three-dimensional constructs provides a method with enhanced physiological relevance due to the relative absence of cellular monolayers within their endogenous micorenvironments. Interestingly, Larkin et al., (2006) describe a method of co-culturing pre-formed self-organising primary rat tendon constructs with isolated myoblasts in place of artificial tendons, to form a functional myotendinous junction in the three-dimensional constructs formed. Functional testing of these constructs revealed the myotendinous junction could withstand tensile forces beyond the physiological range (Larkin et al., 2006). Rivron et al., (2008) further review recent advances in the ability to generate pre-vascularised tissue constructs in vitro which has the capacity to readily anastamose to the host vasculature and thus can enhance viability of implanted tissue constructs. These advances within the tissue engineering field represent promising progress in the development of functional muscles for regenerative purposes.

However due to the differences between native muscle and bioengineered muscle constructs, the challenges which still exist in the formation of de novo skeletal muscle cannot be ignored. Specific challenges still exist in supporting growth of sufficient differentiated muscle tissue for regenerative purposes, the capacity to supply sufficient oxygen and nutrients to the core of the construct, the need for these tissue constructs to remain viable and be vascularised and innervated in vivo (Bach et al., 2004; Birla et al., 2005; Davis et al., 2007; Gawlitta et al., 2007). Overcoming these challenges to achieve maximal therapeutic benefits centres largely around the ability to accurately recapitulate the endogenous environment for growth in vitro. Strategies to enhance myoblast proliferation and differentiation to support these needs are currently in great demand. One such method may be the application of mechanical stretch during construct formation. Endogenously, the electrical impulses generated by the central nervous system are critical developmental stimuli prompting the formation of mature muscle fibres with de-innervated muscle showing reduced numbers of secondary myotubes (Ross et al., 1987). In cell culture models electrical stimulation has been shown to enhance activation of quiescent satellite cells, myoblast alignment, protein synthesis, proliferation and differentiation (Donnelly et al., 2010; Tatsumi et al., 2001; Vandenburgh \& Karlisch, 1989). Sarcomere formation and the development of contractile apparatus have also been shown to be enhanced by electrical 
stimulation in $\mathrm{C}_{2} \mathrm{C}_{12}$ myotubes grown in three-dimensional constructs (Langelaan et al., 2010; Park et al., 2008). An 8 day mechanical stretch/relaxation protocol in bioengineered human muscles also augmented the myofibre diameter and area suggesting adaptation to a phenotype more similar to that of native muscle (Powell et al., 2002). In line with enhanced myotube diameter, Huang et al., (2005) showed that treatment with the trophic factor insulin-like growth factor 1 significantly increased force production of myooids. In further research insulin-like growth factor 1 was shown to induce myotube hypertrophy which was associated with a concomitant increase in active force production (Vandenburgh et al., 2008). This further supports the notion that extracellular paracrine factors are also important in enhancing construct formation. Levenberg et al., (2005) also demonstrated that the coculture of myoblasts with embryonic fibroblasts and endothelial cells promoted the formation of vessel-like structures within the resultant muscle constructs which has the capacity to advance vascularisation in vivo. These findings highlight the significant progress being made in relation to the field bioengineering muscle constructs which resemble native muscle.

\subsubsection{Growth of bioengineered tissue constructs}

The growth of three-dimensional tissue cultures relies on the manipulation of the in vitro environment to support self-organisation of myotubes into bioengineered constructs which resemble the basic structure of in vivo skeletal muscle. Parallel alignment of the myotubes along a uni-directional axis is important if force is to be generated by the construct. The ability of the muscle constructs to generate adequate force to restore muscle function is likely dependent on the provision of an extracellular matrix that facilitates interactions of myofibres in a manner similar to that of native muscle (Bian \& Bursac, 2008). Several forms of scaffold can be used to support organisation including non-biodegradable and biodegradable scaffolds, of which biodegradable scaffolds are preferable as their controlled degradation supports the development of native extracellular matrix and allows for the formation of densely packed myotubes in new muscle tissue (Koning et al., 2009; Rossi et al., 2010). Biodegradable scaffolds which have been employed for myooid growth include polygycolic acid, alginate and hyaluronic acid hydrogels (Kamelger et al., 2004), fibrin (Huang et al., 2005), collagen (Hinds et al., 2011) and lamina gels (Dennis et al., 2001). Biomimetic extracellular scaffolds have been shown to enhance myotube fusion and markers of differentiation in two-dimensional cell culture models (Osses \& Brandan, 2002). These findings can be extrapolated and applied to three-dimensional tissue culture and thus highlights the importance of the extracellular matrix used.

Moreover, the scaffold needs to be biocompatible if the tissue is to be implanted in vivo as this prevents the host's immune system initiating an immune response against the foreign substance (Rossi et al., 2010) which otherwise has the potential to increase the muscle damage sustained. Indeed, recent advances in both skeletal and cardiac muscle engineering have seen bioengineered constructs successfully implanted subcutaneously in rodents (Birla et al., 2005; Levenberg et al., 2005). Birla et al., (2005) initially cultured neonatal cardiac myocytes on laminin coated plates before the bioengineered cardiac constructs were implanted subcutaneously. The authors show the implants become vascularised and cell viability is maintained for at least 3 weeks in vivo (Birla et al., 2005). Levenberg et al., (2005) report similar findings with the bioengineered muscle continuing to differentiate in vivo and 
anastamoses of vessels fabricated in vitro with the host's vasculature, as evidenced by the presence of erythrocytes within the lumen of these vessels. Importantly, the explanted constructs showed spontaneous contractility and force production was augmented compared to in vitro cultured controls (Birla et al., 2005). Moreover, skeletal muscle grafts cultured in collagen/Matrigel ${ }^{\mathrm{TM}}$ hydrogel have been used in myocardial repair subsequent to infarct induced by coronary ligation which was associated with cellular differentiation and vascularisation 4 weeks after implantation (Giraud et al., 2008). These findings represent significant progression towards the end goal of developing implantable tissue constructs and are an important intersect between applications for skeletal and cardiac muscle regeneration.

An additional consideration regarding the appropriateness of various scaffolds culture techniques is the provision of sufficient bioactive signals to replicate the endogenous niche to regulate satellite cells quiescence and myoblast proliferation and differentiation. Reproducing a microenvironment which accurately emulates the endogenous niche of muscle cells is complicated by the distinctive combination of cellular, biochemical and biophysical systems which define the biochemical and structurally properties of the endogenous microenvironment (Cosgrove et al., 2009). Eberli et al., (2009) support the importance of adequately replicating the microenvironment showing that the addition of fibroblast growth factor, epidermal growth factor, dexamethasone and insulin to collagen coated dishes enhances the formation of differentiated human primary myotubes. However, this issue is confounded due to the extensiveness of the list of factors which regulate myogenesis and myotube formation.

The use of Matrigel ${ }^{\mathrm{TM}}$ (BD Biosciences San Jose, CA), a bioactive extracellular matrix derive from the mouse Engelbreth-Holm-Swarm tumour lineage may partially address this issue. Matrigel abundantly produces extracellular matrix factors which support cellular growth and differentiation (reviewed by Kleinman \& Martin (2005)). Given these effects, Matrigel ${ }^{\mathrm{TM}}$ is an appealing substrate to support the fabrication of three-dimensional tissue constructs. Consistent with this, Hinds et al., (2011) found that the use of a hydrogel matrix consisting of Matrigel and fibrin enhanced myotube formation and density within the construct which was positively correlated with force production. Whilst no single extracellular matrix has been identified conclusively as superior, the use of fibrin gels with aprotinin, a plasminogen inhibitor and the naturally occurring cross-linking agent, genipin, have been shown to enhance force production and time-to-failure of constructs by way of controlled degradation of this matrix (Khodabukus \& Baar, 2009). Moreover, fibrin gels provide a more flexible scaffold medium into which cells migrate and proliferate both on top of and within the fibrin gel to increased specific force production (Dennis et al., 2001; Huang et al., 2005). Furthermore, controlled fibrinolysis of the fibrin gel and secretion of extracellular matrix proteins by the muscle cells allows the muscle construct to develop a phenotype more representative of native muscle (Ross \& Tranquillo, 2003). When considered in conjunction with the findings of Hinds et al., (2011) this suggests enhanced fibrin gels to be an appealing substrate for fabrication of bioengineered muscle and accordingly is the method we choose to report herein due to these advantages and also the relative inexpensiveness of substrates and ease at which myooids can be formed.

The methods described are based on previous research in skeletal muscle myotubes (Huang et al., 2005). Methods utilising $C_{2} C_{12}$ myotubes have since been optimised to support an 
extended period for which the constructs can be maintained in culture (Khodabukus \& Baar, 2009). The protocol reported below is based on the optimised procedure.

Myotubes are cultured on polydimethylsiloxane (SYLGARD 184 Elastomer kit; OBA, Dandenong, Australia) coated $35 \mathrm{~mm}$ tissue culture dishes or 6-well tissue culture plates. Prepare the polydimethylsiloxane according to the manufacturer's instructions in a ratio of 10:1 base to curing agent. In brief, using a syringe aspirate $1.5 \mathrm{ml}$ of the base agent and slowly coat the base of each dish, taking care to avoid the formation of air bubbles. Add 150 $\mu \mathrm{l}$ of the curing agent and gently mix with the pipette tip. Allow the dish to cure for 48 hours at room temperature. This process can be quickened by incubating in a humidity-free incubator at $60{ }^{\circ} \mathrm{C}$. Place two $6 \mathrm{~mm}$ long braided silk sutures (Fine Science, North Vancouver, Canada) at either end of the dish with an interposing gap of $12 \mathrm{~mm}$ between the end of each suture. Secure the sutures in place with $0.1 \mathrm{~mm}$-diameter stainless steel minutien pins (Fine Sciences, North Vancouver, Canada) as shown in Figure 2. Place multiple pins along the length of the suture to ensure that they are firmly fixed in place.

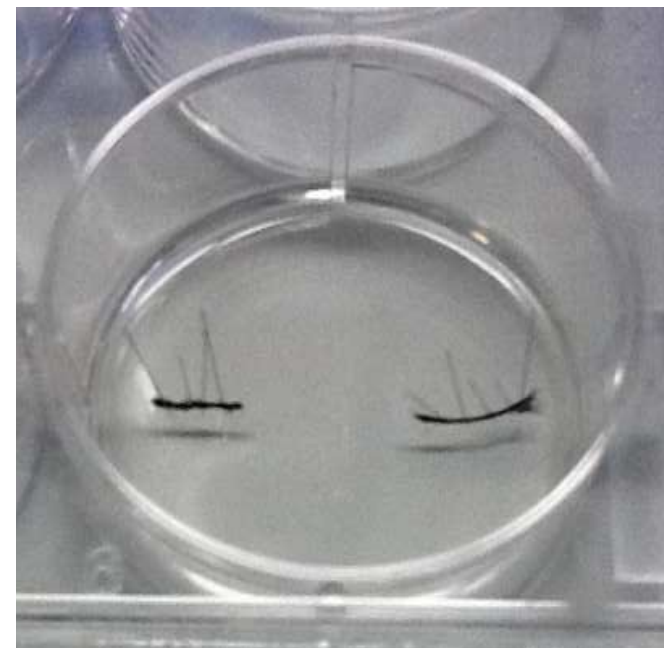

(Cornall et al., Unpublished observation)

Fig. 2. Arrangement of sutures in the polydimethylsiloxane coated well of a 6-well tissue culture plate. As the sutures are to provide the only point of force to which the myotubes align against the suture needs to be firmly affixed with multiple minutien pins along the length of the suture.

At this point it is important to sterilise the dishes to avoid contamination of the myooids constructs. This can be done by soaking the dishes in $70 \%$ ethanol for 20 minutes. Following this, aspirate the ethanol and rinse the dish with $1 \mathrm{ml}$ of $1 x$ phosphate buffered saline. The dishes can also be exposed to UV light for 1 hour to assist with sterilisation.

The next step is the preparation of the fibrin gel. Once all components have been diluted to the appropriate concentrations, determine the number of dishes and prepare a master mix of growth medium, genipin (Sigma Aldrich, St Louis, MO), thrombin (Sigma Aldrich, St Louis, $\mathrm{MO}$ ) and aprotinin (Sigma Aldrich, St Louis, $\mathrm{MO}$ ). $\mathrm{C}_{2} \mathrm{C}_{12}$ myotubes growth medium is made 
with a base of Dulbecco's modified eagle medium supplemented with with $10 \%$ foetal bovine serum $(\mathrm{v} / \mathrm{v}), 1 \%$ penicillin streptomyocin $(\mathrm{v} / \mathrm{v})$ and $0.5 \%$ amphotericin B. For each dish add $463 \mu \mathrm{l}$ of growth medium containing $10 \mu \mathrm{l}$ Genipin (stock concentration 10 $\mathrm{mg} / \mathrm{ml}$ ), $25 \mu \mathrm{l}$ Thrombin (stock concentration $200 \mathrm{U} / \mathrm{ml}$ ) thrombin and $2 \mu \mathrm{l}$ Aprotinin (stock concentration $10 \mathrm{mg} / \mathrm{ml}$ ). Gently agitate the dish until the entire surface is covered, ensure no air bubbles form around the sutures and pins. Quickly, add $200 \mu \mathrm{l}$ of $20 \mathrm{mg} / \mathrm{ml}$ fibrinogen (Sigma Aldrich, St Louis, MO) to each dish and gently mix. Allow the gel to polymerise for 1 hour. Seed the cells into each of the dishes (100,000 cell per dish) in growth medium to a final volume of $2 \mathrm{ml}$. Allow the cells 24 hours to attach prior to changing the growth medium every other day. Myoblasts will migrate through the fibrin gel to proliferate both within and on top of the gel. After 2 days the gel should begin to contract and the myotube will begin to realign themselves between the points of force between the 2 sutures. This process should complete around day 7 . The myotubes are then differentiated for 2 days in reduced serum differentiation medium ( $2 \%$ horse serum). Continue to maintain the forming myooids in growth medium containing $7 \%$ foetal bovine serum until construct formation is completed.

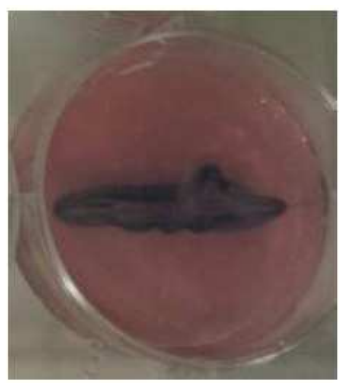

a. Day 4

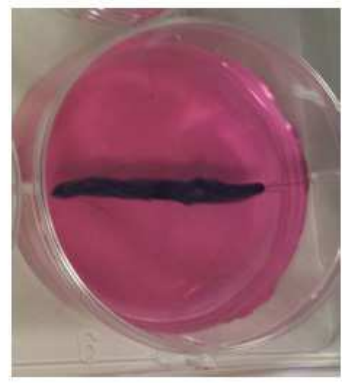

c. Day 7

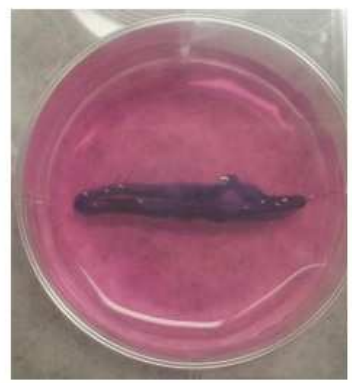

b. Day 5

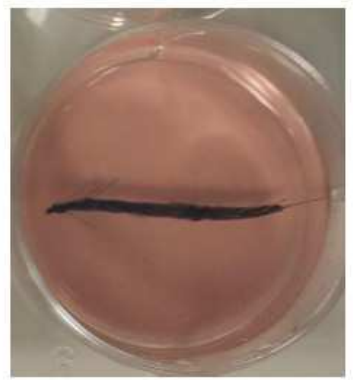

d. Day 16

(Cornall et al., Unpublished observations)

Fig. 3. Formation of three-dimensional $\mathrm{C}_{2} \mathrm{C}_{12}$ tissue constructs at different time points after initial seeding of the cells. Note the progressive contraction of the gel and subsequent alignment of the construct between the two sutures resulting in the formation of a densely packed three-dimensional tissue construct. At day 16 the dimensions of the construct were determined as approximately $25 \mathrm{~mm}$ length and $1 \mathrm{~mm}$ in width and the myooid was deemed to be fully formed. 
Once construct formation is complete the myooids can be stimulated to contract using platinum wire electrodes positioned either side of the constructs using a force transducer. Electrical stimulation of constructs has been successfully demonstrated using clonal $\mathrm{C}_{2} \mathrm{C}_{12}$ myotubes in a number of studies (Khodabukus \& Baar, 2009; Langelaan et al., 2010; Park et al., 2008). However, in our experience the process of electrically stimulating constructs of human primary myotubes has proven difficult. Whilst we have previously been able to culture the human primary myotubes to form bioengineered skeletal muscle constructs, these myooids have been unresponsive to electrical stimulation (McAinch, Unpublished observations). As primary cells have limited myogenic capacity, this may reflect changes in the electrical potential of the membrane as the cells age in culture. It may be possible to form contractile myooids from human primary myotubes which have been isolated from the muscle sample immediately prior to culturing in this manner, as opposed to being passaged in monolayers initially. However, it remains unclear whether contractile ability is retained. Despite the lack of contractile ability, culturing the myotubes in three-dimensional arrangements provides an interesting model providing a more physiologically relevant arrangement of cells (that is, in vivo cells are rarely arranged in monolayers). When cultured in this manner it enables investigations into the importance of cell-cell interactions and spatial arrangements on the maturation and metabolic processes of skeletal muscle myotubes.

\section{Conclusion}

This chapter has highlighted the diverse nature of research applications associated with the use of human primary myotubes for studies investigating muscle physiology and the implications of this for systemic health. We have identified significant benefits of using human primary myotubes over the use of immortalised cell lines such as the $\mathrm{C}_{2} \mathrm{C}_{12}$ and L6 cell lines due to the fact that these cells retain donor phenotypic traits. This increases the physiological relevance of results obtained in studies utilising such primary myotubes. Moreover, the relative ease at which samples of sufficient size can be obtain through simple, relatively non-invasive biopsy techniques heightens the practicality associated with their use. Whilst we have outlined the practices within our research group of isolating myogenic satellite cells, growing and maintaining myoblasts and the differentiation of myoblasts into myotubes for experimentation, it is apparent that significant variations in methodology do prevail. Therefore, the methods described in this chapter may need optimising by the end user depending on the outcomes and clinical measures of the specific study. Accordingly, we recommend these methods as a highly appropriate starting point for this procedure. We have also provided an indication of methods for a number of experimental techniques associated with the use of human primary myotubes for developing bioengineered skeletal muscle constructs and their application for the treatment of various of myopathies. This list of applications is by no means exhaustive which furthers demonstrates the versatile nature of this experimental model.

\section{Acknowledgements}

Lauren Cornall was supported by a scholarship (PB 10M 5472) from the National Heart Foundation of Australia. The authors would also like to acknowledge the support of the 
Biomedical and Lifestyle Diseases Unit within the School of Biomedical and Health Sciences at Victoria University.

\section{References}

Baar, K. 2005, "New dimensions in tissue engineering: possible models for human physiology". Exp Physiol, 90, 799-806, 0958-0670 (Print) 0958-0670 (Linking)

Bach, A. D., Beier, J. P., Stern-Staeter, J. \& Horch, R. E. 2004, "Skeletal muscle tissue engineering". J Cell Mol Med, 8, 413-422, 1582-1838 (Print) 1582-1838 (Linking)

Baron, A. D., Brechtel, G., Wallace, P. \& Edelman, S. V. 1988, "Rates and tissue sites of noninsulin- and insulin-mediated glucose uptake in humans". Am J Physiol, 255, E769774, 0002-9513 (Print) 0002-9513 (Linking)

Bell, J. A., Reed, M. A., Consitt, L. A., Martin, O. J., Haynie, K. R., Hulver, M. W., Muoio, D. M. \& Dohm, G. L. 2010, "Lipid partitioning, incomplete fatty acid oxidation, and insulin signal transduction in primary human muscle cells: effects of severe obesity, fatty acid incubation, and fatty acid translocase/CD36 overexpression". J Clin Endocrinol Metab, 95, 3400-3410, 1945-7197 (Electronic) 0021-972X (Linking)

Berggren, J. R., Tanner, C. J. \& Houmard, J. A. 2007, "Primary cell cultures in the study of human muscle metabolism". Exerc Sport Sci Rev, 35, 56-61, 0091-6331 (Print) 00916331 (Linking)

Bian, W. \& Bursac, N. 2008, "Tissue engineering of functional skeletal muscle: challenges and recent advances". IEEE Eng Med Biol Mag, 27, 109-113, 1937-4186 (Electronic) 0739-5175 (Linking)

Birla, R. K., Borschel, G. H. \& Dennis, R. G. 2005, "In vivo conditioning of tissue-engineered heart muscle improves contractile performance". Artif Organs, 29, 866-875, 0160564X (Print) 0160-564X (Linking)

Blau, H. M., Pavlath, G. K., Hardeman, E. C., Chiu, C. P., Silberstein, L., Webster, S. G., Miller, S. C. \& Webster, C. 1985, "Plasticity of the differentiated state". Science, 230, 758-766, 0036-8075 (Print) 0036-8075 (Linking)

Blau, H. M. \& Webster, C. 1981, "Isolation and characterization of human muscle cells". Proc Natl Acad Sci U S A, 78, 5623-5627, 0027-8424 (Print) 0027-8424 (Linking)

Brand-Saberi, B. \& Christ, B. 1999, "Genetic and epigenetic control of muscle development in vertebrates". Cell Tissue Res, 296, 199-212, 0302-766X (Print) 0302-766X (Linking)

Ceddia, R. B., Somwar, R., Maida, A., Fang, X., Bikopoulos, G. \& Sweeney, G. 2005, "Globular adiponectin increases GLUT4 translocation and glucose uptake but reduces glycogen synthesis in rat skeletal muscle cells". Diabetologia, 48, 132-139, 0012-186X (Print) 0012-186X (Linking)

Charge, S. B. \& Rudnicki, M. A. 2004, "Cellular and molecular regulation of muscle regeneration". Physiol Rev, 84, 209-238, 0031-9333 (Print) 0031-9333 (Linking)

Chen, M. B., Mcainch, A. J., Macaulay, S. L., Castelli, L. A., O'brien P, E., Dixon, J. B., Cameron-Smith, D., Kemp, B. E. \& Steinberg, G. R. 2005, "Impaired activation of AMP-kinase and fatty acid oxidation by globular adiponectin in cultured human skeletal muscle of obese type 2 diabetics". J Clin Endocrinol Metab, 90, 3665-3672, 0021-972X (Print) 0021-972X (Linking)

Ciaraldi, T. P., Abrams, L., Nikoulina, S., Mudaliar, S. \& Henry, R. R. 1995, "Glucose transport in cultured human skeletal muscle cells. Regulation by insulin and 
glucose in nondiabetic and non-insulin-dependent diabetes mellitus subjects". J Clin Invest, 96, 2820-2827, 0021-9738 (Print) 0021-9738 (Linking)

Condon, J., Yin, S., Mayhew, B., Word, R. A., Wright, W. E., Shay, J. W. \& Rainey, W. E. 2002, "Telomerase immortalization of human myometrial cells". Biol Reprod, 67, 506514, 0006-3363 (Print) 0006-3363 (Linking)

Cosgrove, B. D., Sacco, A., Gilbert, P. M. \& Blau, H. M. 2009, "A home away from home: challenges and opportunities in engineering in vitro muscle satellite cell niches". Differentiation, 78, 185-194, 1432-0436 (Electronic) 0301-4681 (Linking)

Das, M., Rumsey, J. W., Bhargava, N., Gregory, C., Riedel, L., Kang, J. F. \& Hickman, J. J. 2009, "Developing a novel serum-free cell culture model of skeletal muscle differentiation by systematically studying the role of different growth factors in myotube formation". In Vitro Cell Dev Biol Anim, 45, 378-387, 1543-706X (Electronic) 1071-2690 (Linking)

Davis, B. H., Schroeder, T., Yarmolenko, P. S., Guilak, F., Dewhirst, M. W. \& Taylor, D. A. 2007, "An in vitro system to evaluate the effects of ischemia on survival of cells used for cell therapy". Ann Biomed Eng, 35, 1414-1424, 0090-6964 (Print) 0090-6964 (Linking)

Deasy, B. M., Jankowski, R. J. \& Huard, J. 2001, "Muscle-derived stem cells: characterization and potential for cell-mediated therapy". Blood Cells Mol Dis, 27, 924-933, 1079-9796 (Print) 1079-9796 (Linking)

Dennis, R. G., Kosnik, P. E., 2nd, Gilbert, M. E. \& Faulkner, J. A. 2001, "Excitability and contractility of skeletal muscle engineered from primary cultures and cell lines". Am J Physiol Cell Physiol, 280, C288-295, 0363-6143 (Print) 0363-6143 (Linking)

Derry, K. L., Nicolle, M. N., Keith-Rokosh, J. A. \& Hammond, R. R. 2009, "Percutaneous muscle biopsies: review of 900 consecutive cases at London Health Sciences Centre". Can J Neurol Sci, 36, 201-206, 0317-1671 (Print) 0317-1671 (Linking)

Di Donna, S., Mamchaoui, K., Cooper, R. N., Seigneurin-Venin, S., Tremblay, J., ButlerBrowne, G. S. \& Mouly, V. 2003, "Telomerase can extend the proliferative capacity of human myoblasts, but does not lead to their immortalization". Mol Cancer Res, 1, 643-653, 1541-7786 (Print) 1541-7786 (Linking)

Dietrichson, P., Coakley, J., Smith, P. E., Griffiths, R. D., Helliwell, T. R. \& Edwards, R. H. 1987, "Conchotome and needle percutaneous biopsy of skeletal muscle". J Neurol Neurosurg Psychiatry, 50, 1461-1467, 0022-3050 (Print) 0022-3050 (Linking)

Donnelly, K., Khodabukus, A., Philp, A., Deldicque, L., Dennis, R. G. \& Baar, K. 2010, "A novel bioreactor for stimulating skeletal muscle in vitro". Tissue Eng Part C Methods, 16, 711-718, 1937-3392 (Electronic) 937-3384 (Linking)

Douillard-Guilloux, G., Mouly, V., Caillaud, C. \& Richard, E. 2009, "Immortalization of murine muscle cells from lysosomal alpha-glucosidase deficient mice: a new tool to study pathophysiology and assess therapeutic strategies for Pompe disease". Biochem Biophys Res Commun, 388, 333-338, 1090-2104 (Electronic) 0006-291X (Linking)

Eberli, D., Soker, S., Atala, A. \& Yoo, J. J. 2009, "Optimization of human skeletal muscle precursor cell culture and myofiber formation in vitro". Methods, 47, 98-103, 10959130 (Electronic) 1046-2023 (Linking) 
Edwards, R. H., Round, J. M. \& Jones, D. A. 1983, "Needle biopsy of skeletal muscle: a review of 10 years experience". Muscle Nerve, 6, 676-683, 0148-639X (Print) 0148639X (Linking)

Efrat, S., Linde, S., Kofod, H., Spector, D., Delannoy, M., Grant, S., Hanahan, D. \& Baekkeskov, S. 1988, "Beta-cell lines derived from transgenic mice expressing a hybrid insulin gene-oncogene". Proc Natl Acad Sci U S A, 85, 9037-9041, 0027-8424 (Print) 0027-8424 (Linking)

Eschenhagen, T., Didie, M., Heubach, J., Ravens, U. \& Zimmermann, W. H. 2002, "Cardiac tissue engineering". Transpl Immunol, 9, 315-321, 0966-3274 (Print) 0966-3274 (Linking)

Fediuc, S., Gaidhu, M. P. \& Ceddia, R. B. 2006, "Regulation of AMP-activated protein kinase and acetyl-CoA carboxylase phosphorylation by palmitate in skeletal muscle cells". J Lipid Res, 47, 412-420, 0022-2275 (Print) 0022-2275 (Linking)

Fediuc, S., Pimenta, A. S., Gaidhu, M. P. \& Ceddia, R. B. 2008, "Activation of AMP-activated protein kinase, inhibition of pyruvate dehydrogenase activity, and redistribution of substrate partitioning mediate the acute insulin-sensitizing effects of troglitazone in skeletal muscle cells". J Cell Physiol, 215, 392-400, 1097-4652 (Electronic) 0021-9541 (Linking)

Fletcher, L. M., Welsh, G. I., Oatey, P. B. \& Tavare, J. M. 2000, "Role for the microtubule cytoskeleton in GLUT4 vesicle trafficking and in the regulation of insulinstimulated glucose uptake". Biochem J, 352 Pt 2, 267-276, 0264-6021 (Print) 0264-6021 (Linking)

Gaster, M., Beck-Nielsen, H. \& Schroder, H. D. 2001a, "Proliferation conditions for human satellite cells. The fractional content of satellite cells". APMIS, 109, 726-734, 09034641 (Print) 0903-4641 (Linking)

Gaster, M., Kristensen, S. R., Beck-Nielsen, H. \& Schroder, H. D. 2001b, "A cellular model system of differentiated human myotubes". APMIS, 109, 735-744, 0903-4641 (Print) 0903-4641 (Linking)

Gaster, M., Rustan, A. C., Aas, V. \& Beck-Nielsen, H. 2004, "Reduced lipid oxidation in skeletal muscle from type 2 diabetic subjects may be of genetic origin: evidence from cultured myotubes". Diabetes, 53, 542-548, 0012-1797 (Print) 0012-1797 (Linking)

Gawlitta, D., Oomens, C. W., Bader, D. L., Baaijens, F. P. \& Bouten, C. V. 2007, "Temporal differences in the influence of ischemic factors and deformation on the metabolism of engineered skeletal muscle". J Appl Physiol, 103, 464-473, 8750-7587 (Print) 01617567 (Linking)

Giraud, M. N., Ayuni, E., Cook, S., Siepe, M., Carrel, T. P. \& Tevaearai, H. T. 2008, "Hydrogel-based engineered skeletal muscle grafts normalize heart function early after myocardial infarction". Artif Organs, 32, 692-700, 1525-1594 (Electronic) 0160$564 X$ (Linking)

Heid, C. A., Stevens, J., Livak, K. J. \& Williams, P. M. 1996, "Real time quantitative PCR". Genome Res, 6, 986-994, 1088-9051 (Print) 1088-9051 (Linking)

Hinds, S., Bian, W., Dennis, R. G. \& Bursac, N. 2011, "The role of extracellular matrix composition in structure and function of bioengineered skeletal muscle". Biomaterials, 32, 3575-3583, 1878-5905 (Electronic) 0142-9612 (Linking) 
Huang, Y. C., Dennis, R. G., Larkin, L. \& Baar, K. 2005, "Rapid formation of functional muscle in vitro using fibrin gels". J Appl Physiol, 98, 706-713, 8750-7587 (Print) 01617567 (Linking)

Jat, P. S., Noble, M. D., Ataliotis, P., Tanaka, Y., Yannoutsos, N., Larsen, L. \& Kioussis, D. 1991, "Direct derivation of conditionally immortal cell lines from an H-2Kb-tsA58 transgenic mouse". Proc Natl Acad Sci U S A, 88, 5096-5100, 0027-8424 (Print) 00278424 (Linking)

Kamelger, F. S., Marksteiner, R., Margreiter, E., Klima, G., Wechselberger, G., Hering, S. \& Piza, H. 2004, "A comparative study of three different biomaterials in the engineering of skeletal muscle using a rat animal model". Biomaterials, 25, 16491655, 0142-9612 (Print) 0142-9612 (Linking)

Kessler, P. D., Podsakoff, G. M., Chen, X., Mcquiston, S. A., Colosi, P. C., Matelis, L. A., Kurtzman, G. J. \& Byrne, B. J. 1996, "Gene delivery to skeletal muscle results in sustained expression and systemic delivery of a therapeutic protein". Proc Natl Acad Sci U S A, 93, 14082-14087, 0027-8424 (Print) 0027-8424 (Linking)

Khodabukus, A. \& Baar, K. 2009, "Regulating fibrinolysis to engineer skeletal muscle from the C2C12 cell line". Tissue Eng Part C Methods, 15, 501-511, 1937-3392 (Electronic) 1937-3384 (Linking)

Kleinman, H. K. \& Martin, G. R. 2005, "Matrigel: basement membrane matrix with biological activity". Semin Cancer Biol, 15, 378-386, 1044-579X (Print) 1044-579X (Linking)

Kletzien, R. F., Perdue, J. F. \& Springer, A. 1972, "Cytochalasin A and B. Inhibition of sugar uptake in cultured cells". J Biol Chem, 247, 2964-2966, 0021-9258 (Print) 0021-9258 (Linking)

Klip, A., Li, G. \& Logan, W. J. 1984, "Induction of sugar uptake response to insulin by serum depletion in fusing L6 myoblasts". Am J Physiol, 247, E291-296, 0002-9513 (Print) 0002-9513 (Linking)

Koning, M., Harmsen, M. C., Van Luyn, M. J. \& Werker, P. M. 2009, "Current opportunities and challenges in skeletal muscle tissue engineering". J Tissue Eng Regen Med, 3, 407-415, 1932-7005 (Electronic) 1932-6254 (Linking)

Kuhl, U., Ocalan, M., Timpl, R. \& Von Der Mark, K. 1986, "Role of laminin and fibronectin in selecting myogenic versus fibrogenic cells from skeletal muscle cells in vitro". Dev Biol, 117, 628-635, 0012-1606 (Print) 0012-1606 (Linking)

Lagord, C., Soulet, L., Bonavaud, S., Bassaglia, Y., Rey, C., Barlovatz-Meimon, G., Gautron, J. \& Martelly, I. 1998, "Differential myogenicity of satellite cells isolated from extensor digitorum longus (EDL) and soleus rat muscles revealed in vitro". Cell Tissue Res, 291, 455-468, 0302-766X (Print) 0302-766X (Linking)

Langelaan, M. L., Boonen, K. J., Rosaria-Chak, K. Y., Van Der Schaft, D. W., Post, M. J. \& Baaijens, F. P. 2010, "Advanced maturation by electrical stimulation: Differences in response between $\mathrm{C} 2 \mathrm{C} 12$ and primary muscle progenitor cells". J Tissue Eng Regen Med, 1932-7005 (Electronic) 1932-6254 (Linking)

Langen, R. C., Schols, A. M., Kelders, M. C., Wouters, E. F. \& Janssen-Heininger, Y. M. 2003, "Enhanced myogenic differentiation by extracellular matrix is regulated the early stages of myogenesis". In Vitro Cell Dev Biol Anim, 39, 163-169, 1071-2690 (Print) 1071-2690 (Linking) 
Larkin, L. M., Calve, S., Kostrominova, T. Y. \& Arruda, E. M. 2006, "Structure and functional evaluation of tendon-skeletal muscle constructs engineered in vitro". Tissue Eng, 12, 3149-3158, 1076-3279 (Print) 1076-3279 (Linking)

Levenberg, S., Rouwkema, J., Macdonald, M., Garfein, E. S., Kohane, D. S., Darland, D. C., Marini, R., Van Blitterswijk, C. A., Mulligan, R. C., D'amore, P. A. \& Langer, R. 2005, "Engineering vascularized skeletal muscle tissue". Nat Biotechnol, 23, 879-884, 1087-0156 (Print) 1087-0156 (Linking)

Linkhart, T. A., Clegg, C. H. \& Hauschika, S. D. 1981, "Myogenic differentiation in permanent clonal mouse myoblast cell lines: regulation by macromolecular growth factors in the culture medium". Dev Biol, 86, 19-30, 0012-1606 (Print) 0012-1606 (Linking)

Livak, K. J. \& Schmittgen, T. D. 2001, "Analysis of relative gene expression data using realtime quantitative PCR and the 2(-Delta Delta C(T)) Method". Methods, 25, 402-408, 1046-2023 (Print) 1046-2023 (Linking)

Loro, E., Rinaldi, F., Malena, A., Masiero, E., Novelli, G., Angelini, C., Romeo, V., Sandri, M., Botta, A. \& Vergani, L. 2010, "Normal myogenesis and increased apoptosis in myotonic dystrophy type-1 muscle cells". Cell Death Differ, 17, 1315-1324, 1476-5403 (Electronic) 1350-9047 (Linking)

Machida, S., Spangenburg, E. E. \& Booth, F. W. 2004, "Primary rat muscle progenitor cells have decreased proliferation and myotube formation during passages". Cell Prolif, 37, 267-277, 0960-7722 (Print) 0960-7722 (Linking)

Macpherson, P. C., Suhr, S. T. \& Goldman, D. 2004, "Activity-dependent gene regulation in conditionally-immortalized muscle precursor cell lines". J Cell Biochem, 91, 821-839, 0730-2312 (Print) 0730-2312 (Linking)

Mauro, A. 1961, "Satellite cell of skeletal muscle fibers". J Biophys Biochem Cytol, 9, 493-495, 0095-9901 (Print) 0095-9901 (Linking)

Mcainch, A. J. \& Cameron-Smith, D. 2009, "Adiponectin decreases pyruvate dehydrogenase kinase 4 gene expression in obese- and diabetic-derived myotubes". Diabetes Obes Metab, 11, 721-728, 1463-1326 (Electronic) 1462-8902 (Linking)

Mcainch, A. J., Steinberg, G. R., Chen, M. B., O'brien, P. E., Dixon, J. B., Cameron-Smith, D. \& Kemp, B. E. 2006a, "The suppressor of cytokine signaling 3 inhibits leptin activation of AMP-kinase in cultured skeletal muscle of obese humans". J Clin Endocrinol Metab, 91, 3592-3597, 0021-972X (Print) 0021-972X (Linking)

Mcainch, A. J., Steinberg, G. R., Mollica, J., O'brien, P. E., Dixon, J. B., Macaulay, S. L., Kemp, B. E. \& Cameron-Smith, D. 2006b, "Differential regulation of adiponectin receptor gene expression by adiponectin and leptin in myotubes derived from obese and diabetic individuals". Obesity (Silver Spring), 14, 1898-1904, 1930-7381 (Print)

Mcainch, A. J., Steinberg, G. R., Mollica, J., O'brien, P. E., Dixon, J. B., Kemp, B. E. \& Cameron-Smith, D. 2007, "Leptin stimulation of COXIV is impaired in obese skeletal muscle myotubes". Obes Res Clin Pract, 1, 53-60, 1871-403X

Melendez, M. M., Vosswinkel, J. A., Shapiro, M. J., Gelato, M. C., Mynarcik, D., Gavi, S., Xu, X. \& Mcnurlan, M. 2007, "Wall suction applied to needle muscle biopsy - a novel technique for increasing sample size". J Surg Res, 142, 301-303, 0022-4804 (Print) 0022-4804 (Linking)

Michael, L. F., Wu, Z., Cheatham, R. B., Puigserver, P., Adelmant, G., Lehman, J. J., Kelly, D. P. \& Spiegelman, B. M. 2001, "Restoration of insulin-sensitive glucose transporter 
(GLUT4) gene expression in muscle cells by the transcriptional coactivator PGC-1". Proc Natl Acad Sci U S A, 98, 3820-3825, 0027-8424 (Print) 0027-8424 (Linking)

Mitsumoto, Y., Burdett, E., Grant, A. \& Klip, A. 1991, "Differential expression of the GLUT1 and GLUT4 glucose transporters during differentiation of L6 muscle cells". Biochem Biophys Res Commun, 175, 652-659, 0006-291X (Print) 0006-291X (Linking)

Mott, D. M., Hoyt, C., Caspari, R., Stone, K., Pratley, R. \& Bogardus, C. 2000, "Palmitate oxidation rate and action on glycogen synthase in myoblasts from insulin-resistant subjects". Am J Physiol Endocrinol Metab, 279, E561-569, 0193-1849 (Print) 0193-1849 (Linking)

Obinata, M. 2001, "Possible applications of conditionally immortalized tissue cell lines with differentiation functions". Biochem Biophys Res Commun, 286, 667-672, 0006-291X (Print) 0006-291X (Linking)

Osses, N. \& Brandan, E. 2002, "ECM is required for skeletal muscle differentiation independently of muscle regulatory factor expression". Am J Physiol Cell Physiol, 282, C383-394, 0363-6143 (Print) 0363-6143 (Linking)

Park, H., Bhalla, R., Saigal, R., Radisic, M., Watson, N., Langer, R. \& Vunjak-Novakovic, G. 2008, "Effects of electrical stimulation in C2C12 muscle constructs". J Tissue Eng Regen Med, 2, 279-287, 1932-6254 (Print) 1932-6254 (Linking)

Pathmaperuma, A. N., Mana, P., Cheung, S. N., Kugathas, K., Josiah, A., Koina, M. E., Broomfield, A., Delghingaro-Augusto, V., Ellwood, D. A., Dahlstrom, J. E. \& Nolan, C. J. 2010, "Fatty acids alter glycerolipid metabolism and induce lipid droplet formation, syncytialisation and cytokine production in human trophoblasts with minimal glucose effect or interaction". Placenta, 31, 230-239, 1532-3102 (Electronic) 0143-4004 (Linking)

Petersen, E. W., Carey, A. L., Sacchetti, M., Steinberg, G. R., Macaulay, S. L., Febbraio, M. A. \& Pedersen, B. K. 2005, "Acute IL-6 treatment increases fatty acid turnover in elderly humans in vivo and in tissue culture in vitro". Am J Physiol Endocrinol Metab, 288, E155-162, 0193-1849 (Print) 0193-1849 (Linking)

Pimenta, A. S., Gaidhu, M. P., Habib, S., So, M., Fediuc, S., Mirpourian, M., Musheev, M., Curi, R. \& Ceddia, R. B. 2008, "Prolonged exposure to palmitate impairs fatty acid oxidation despite activation of AMP-activated protein kinase in skeletal muscle cells". J Cell Physiol, 217, 478-485, 1097-4652 (Electronic) 0021-9541 (Linking)

Powell, C. A., Smiley, B. L., Mills, J. \& Vandenburgh, H. H. 2002, "Mechanical stimulation improves tissue-engineered human skeletal muscle". Am J Physiol Cell Physiol, 283, C1557-1565, 0363-6143 (Print) 0363-6143 (Linking)

Richler, C. \& Yaffe, D. 1970, "The in vitro cultivation and differentiation capacities of myogenic cell lines". Dev Biol, 23, 1-22, 0012-1606 (Print) 0012-1606 (Linking)

Ridley, A. J., Paterson, H. F., Noble, M. \& Land, H. 1988, "Ras-mediated cell cycle arrest is altered by nuclear oncogenes to induce Schwann cell transformation". EMBO J, 7, 1635-1645, 0261-4189 (Print) 0261-4189 (Linking)

Rivron, N. C., Liu, J. J., Rouwkema, J., De Boer, J. \& Van Blitterswijk, C. A. 2008, "Engineering vascularised tissues in vitro". Eur Cell Mater, 15, 27-40, 1473-2262 (Electronic) 1473-2262 (Linking)

Ross, J. J., Duxson, M. J. \& Harris, A. J. 1987, "Neural determination of muscle fibre numbers in embryonic rat lumbrical muscles". Development, 100, 395-409, 0950-1991 (Print) 0950-1991 (Linking) 
Ross, J. J. \& Tranquillo, R. T. 2003, "ECM gene expression correlates with in vitro tissue growth and development in fibrin gel remodeled by neonatal smooth muscle cells". Matrix Biol, 22, 477-490, 0945-053X (Print) 0945-053X (Linking)

Rossi, C. A., Pozzobon, M. \& De Coppi, P. 2010, "Advances in musculoskeletal tissue engineering: moving towards therapy". Organogenesis, 6, 167-172, 1555-8592 (Electronic) 1547-6278 (Linking)

Santella, R. M. 2006, "Approaches to DNA/RNA Extraction and whole genome amplification". Cancer Epidemiol Biomarkers Prev, 15, 1585-1587, 1055-9965 (Print) 1055-9965 (Linking)

Steinberg, G. R., Mcainch, A. J., Chen, M. B., O'brien, P. E., Dixon, J. B., Cameron-Smith, D. \& Kemp, B. E. 2006, "The suppressor of cytokine signaling 3 inhibits leptin activation of AMP-kinase in cultured skeletal muscle of obese humans". J Clin Endocrinol Metab, 91, 3592-3597, 0021-972X (Print) 0021-972X (Linking)

Stern-Straeter, J., Bran, G., Riedel, F., Sauter, A., Hormann, K. \& Goessler, U. R. 2008, "Characterization of human myoblast cultures for tissue engineering". Int J Mol Med, 21, 49-56, 1107-3756 (Print) 1107-3756 (Linking)

Stern-Straeter, J., Riedel, F., Bran, G., Hormann, K. \& Goessler, U. R. 2007, "Advances in skeletal muscle tissue engineering". In Vivo, 21, 435-444, 0258-851X (Print) 0258851X (Linking)

Tarnopolsky, M. A., Pearce, E., Smith, K. \& Lach, B. 2011, "Suction-modified Bergstrom muscle biopsy technique: experience with 13,500 procedures". Muscle Nerve, 43, 717-725, 1097-4598 (Electronic) 0148-639X (Linking)

Tatsumi, R., Sheehan, S. M., Iwasaki, H., Hattori, A. \& Allen, R. E. 2001, "Mechanical stretch induces activation of skeletal muscle satellite cells in vitro". Exp Cell Res, 267, 107114, 0014-4827 (Print) 0014-4827 (Linking)

Thompson, D. B., Pratley, R. \& Ossowski, V. 1996, "Human primary myoblast cell cultures from non-diabetic insulin resistant subjects retain defects in insulin action". J Clin Invest, 98, 2346-2350, 0021-9738 (Print) 0021-9738 (Linking)

Todaro, G. J. \& Green, H. 1963, "Quantitative studies of the growth of mouse embryo cells in culture and their development into established lines". J Cell Biol, 17, 299-313, 00219525 (Print) 0021-9525 (Linking)

Todaro, G. J., Nilausen, K. \& Green, H. 1963, "Growth Properties of Polyoma Virus-Induced Hamster Tumor Cells". Cancer Res, 23, 825-832, 0008-5472 (Print) 0008-5472 (Linking)

Vandenburgh, H. 2010, "High-content drug screening with engineered musculoskeletal tissues". Tissue Eng Part B Rev, 16, 55-64, 1937-3376 (Electronic) 1937-3368 (Linking)

Vandenburgh, H., Shansky, J., Benesch-Lee, F., Barbata, V., Reid, J., Thorrez, L., Valentini, R. \& Crawford, G. 2008, "Drug-screening platform based on the contractility of tissueengineered muscle". Muscle Nerve, 37, 438-447, 0148-639X (Print) 0148-639X (Linking)

Vandenburgh, H. H. \& Karlisch, P. 1989, "Longitudinal growth of skeletal myotubes in vitro in a new horizontal mechanical cell stimulator". In Vitro Cell Dev Biol, 25, 607-616, 0883-8364 (Print) 0883-8364 (Linking)

Watt, M. J., Steinberg, G. R., Chen, Z. P., Kemp, B. E. \& Febbraio, M. A. 2006, "Fatty acids stimulate AMP-activated protein kinase and enhance fatty acid oxidation in L6 myotubes". J Physiol, 574, 139-147, 0022-3751 (Print) 0022-3751 (Linking) 
Yaffe, D. 1968, "Retention of differentiation potentialities during prolonged cultivation of myogenic cells". Proc Natl Acad Sci U S A, 61, 477-483, 0027-8424 (Print) 0027-8424 (Linking)

Yaffe, D. \& Saxel, O. 1977, "Serial passaging and differentiation of myogenic cells isolated from dystrophic mouse muscle". Nature, 270, 725-727, 0028-0836 (Print) 0028-0836 (Linking)

Zurlo, F., Larson, K., Bogardus, C. \& Ravussin, E. 1990, "Skeletal muscle metabolism is a major determinant of resting energy expenditure". J Clin Invest, 86, 1423-1427, 00219738 (Print) 0021-9738 (Linking) 


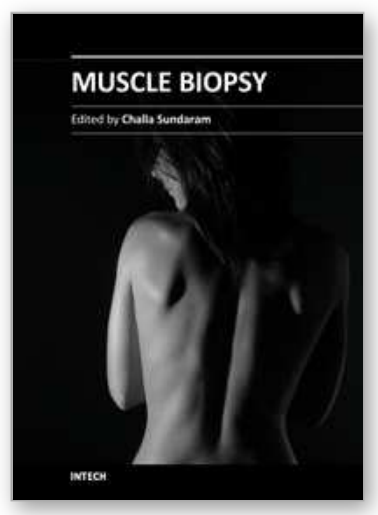

\author{
Muscle Biopsy \\ Edited by Dr. Challa Sundaram
}

ISBN 978-953-307-778-9

Hard cover, 154 pages

Publisher InTech

Published online 05, January, 2012

Published in print edition January, 2012

Investigation of muscle diseases has changed dramatically with the understanding of genetic basis of a wide range of muscle diseases. Muscle biopsy has become a powerful tool not only to provide diagnosis but to make tissue available for genetic studies and to basic scientists for biomedical research. Accurate interpretation of muscle biopsy to detect cell dysfunction/ damage/death or absence / abnormality of a protein or genetic defect by the sophisticated technologies is important to guide treatment of various muscle diseases. In this book on muscle biopsy various chapters deal with the procedure and interpretation of muscle biopsy, its use in the culture of myotubes and membrane transport studies.Muscle biopsy is an important technique to investigate mitochondrial dysfunction and the mitochondrial DNA integrity in oxidation. Phosphorylation in various metabolic diseases like obesity, type 2 diabetes mellitus and peripheral vascular disease is explored in the other chapters with detailed descriptions on methodology. This book provides the advances in the basic techniques of muscle biopsy for a neuroscientist.

\title{
How to reference
}

In order to correctly reference this scholarly work, feel free to copy and paste the following:

Lauren Cornall, Deanne Hryciw, Michael Mathai and Andrew McAinch (2012). Generation and Use of Cultured Human Primary Myotubes, Muscle Biopsy, Dr. Challa Sundaram (Ed.), ISBN: 978-953-307-778-9, InTech, Available from: http://www.intechopen.com/books/muscle-biopsy/generation-and-use-of-cultured-humanprimary-myotubes

\section{INTECH}

open science | open minds

\section{InTech Europe}

University Campus STeP Ri

Slavka Krautzeka 83/A

51000 Rijeka, Croatia

Phone: +385 (51) 770447

Fax: +385 (51) 686166

www.intechopen.com

\section{InTech China}

Unit 405, Office Block, Hotel Equatorial Shanghai

No.65, Yan An Road (West), Shanghai, 200040, China

中国上海市延安西路65号上海国际贵都大饭店办公楼405单元

Phone: +86-21-62489820

Fax: $+86-21-62489821$ 
(C) 2012 The Author(s). Licensee IntechOpen. This is an open access article distributed under the terms of the Creative Commons Attribution 3.0 License, which permits unrestricted use, distribution, and reproduction in any medium, provided the original work is properly cited. 